\title{
Türkiye'deki Üniversite Öğrencilerinin Kitap Okuma Profilleri
}

\author{
DR. ÖĞR. ÜYESİ YAKUP ALAN*
}

\begin{abstract}
Öz
Çağdaş ve gelişmiş bir toplum olmanın önemli ölçütlerinden biri toplumların okuma alışkanlığına sahip bireylere sahip olmasıdır. Üniversite öğrencilerinden de okuma alışkanlığı yüksek bireyler olmaları beklenmektedir. Bu araştırmanın amacı, Türkiye'deki devlet üniversitelerinde lisans eğitimi alan öğrencilerin okuyucu profillerini ortaya çıkarmaktır. Araştırmada nicel araştırma yöntemlerinden tarama araştırması kullanılmıştır. Araştırmanın örneklemini Türkiye'nin yedi bölgesinde ve farklı illerinde bulunan 19 devlet üniversitesinin 17 farklı fakültesinde eğitim alan 1580 lisans öğrencisi oluşturmaktadır. Araştırmada, verileri elde etmek amacıyla araştırmacı tarafından hazırlanan Kitap Okuma Profilleri Anketi kullanılmıştır. Verilerin çözümlenmesinde betimsel istatistiksel analiz yöntemleri kullanılmış ve elde edilen verilerin yüzde (\%) ve frekans (f) değerleri hesaplanmıştır. Yapılan analizler sonucunda; üniversite öğrencilerinin genel olarak düzenli kitap okuyucusu olduğu, kitap okuma alışkanlığı kazanmada en önemli faktörün aile olduğu, öğrencilerin daha çok yerli eserleri tercih ettikleri, elektronik aletleri ve interneti genel anlamda kitap okuma amacıyla kullanmadıkları, daha çok macera ve bilim kurgu konulu eserleri tercih ettikleri, telefonun en büyük kitap okuma engeli olduğu, öğrencilerin kitaplarını genel olarak satın alarak temin ettikleri, kitap seçiminde en büyük faktörün kitabın konusu olduğu, öğrencilerin zengin bir kitaplığa sahip olmadıkları ve öğrencilerinin çoğunun orta düzey veya zayıf okuyucu profillerine uygun olduğu tespit edilmiştir.
\end{abstract}

Anahtar sözcükler: Kitap, okuma, okuma profili, üniversite öğrencileri, anket

\section{READING PROFILES OF UNIVERSITY STUDENTS IN TURKEY}

\section{Abstract}

One of the important criteria of being a modern and developed society is that societies have individuals with reading habits. University students are also expected to be individuals with high reading habits. The purpose of this research is to reveal the reading profiles of undergraduate students at public universities in Turkey. Survey research, one of the quantitative research methods was used in the study. 1580 undergraduate students studying in 17 different faculties of 19 public universities, located in seven regions and different provinces of Turkey, constitutes the sample of research. In the study, the Book Reading Profiles Questionnaire prepared by the researcher was used to obtain the data. Descriptive statistical analysis methods were used to

\footnotetext{
Kilis 7 Aralık Üniversitesi, alanyakup@gmail.com, orcid.org/0000-0002-9888-1357 
analyze the data and the percentage (\%) and frequency (f) values of the obtained data were calculated. It was found as a result of the analyses that: university students read books regularly, that the most important factor in gaining the habit of reading books is the family, that students prefer mostly domestic works, that they do not generally use electronic devices and internet for reading purposes, that they prefer adventure and science fiction books, that mobile phones are the biggest obstacle to reading, that students usually obtain their books by buying, that the most important factor in choosing the books is the theme, that students do not have a rich library and most students are suitable for intermediate or weak reader profiles.

Keywords: Book, reading, reading profile, university students, survey

\section{GİRIŞ}

7 ğitimin başlangıcından beri kaliteli insan yetiştirmek, gerçekleştirilen eğitim faaliyetlerinin en önemli amaçlarından biri olmuştur (Karatay, 2011, s. 1399). Çünkü

bir toplumun kalite düzeyi ile o toplumda yaşayan insanların kalite düzeyleri arasında oldukça sıkı bir ilişki vardır. Eğitim çalışmaları da bu sıkı ilişki dikkate alınarak yürütülmekte ve daha kaliteli bir toplum için daha nitelikli insanlar yetiştirilmeye çalışılmaktadır.

Nitelikli insan yetiştirmenin bazı ölçütleri vardır. Bu ölçütler; sorgulayan, düşünen, araştıran, üreten, problemleri çözen, toplumuna ve kendisine faydalı, değerleri benimseyen ve aktaran bireyler ortaya çıkarmak olarak sıralanabilir. Günümüz eğitim anlayışları da bilgiyi sadece alan/ezberleyen değil o bilgiye nasıl ulaşacağını bilen ve o bilgiyi anlayarak hayatında uygulayan bireylerin yetiştirilmesi gerektiğini savunmaktadır. Yine günümüz eğitim dünyasında önemli bir yer tutan yaşam boyu öğrenme kavramı da üst düzey zihinsel becerilerini kullanabilen, bilgiyi tüketen ve üreten, öğrenmeyi öğrenmiş bireyler üzerine yoğunlaşmaktadır. Dünyanın yaşadığ1 hızlı değişim ve gelişime ayak uydurabilmek ve yaşam boyu öğrenmenin sağlıklı devam ettirilebilmek için gerekli şartlardan biri de bireylere okuma alışkanlığı kazandırmaktır (Yıldız vd., 2015, s. 144).

Bir yazıyı meydana getiren harf ve işaretlere bakıp bunları çözümlemek veya seslendirmek (Türkçe Sözlük, 2011, s. 1793) olarak tanımlanabilen okuma; dil merkezli anlama süreçlerinden biridir ve alıcının metin karşısında yaptığı düşünsel bir etkinliktir (Onan, 2013, s. 179). Akyol da okumayı bir amaç doğrultusunda gerçekleştirilen anlama süreci olarak tanımlamaktadır (2005, s. 1). Başka bir tanıma göre ise okuma; bir metnin harflerini, kelimelerini tanımak ve bunların anlamlarını kavramaktır ve bu süreç çok boyutludur. Fizyolojik ve ruhsal boyutun işe katılması gerekmektedir (Göğüş, 1978, s. 60).

Okuma süreci ailede başlar ve bu eylem oldukça uzun bir zamanı alır (Camp, 2007, s. 257). Ailede okuma etkinlikleri gören ve bu etkinliklere katılan çocuk her yerde bu tür etkinlikleri arar. Eğitim sürecinin başlamasıyla birlikte de okulların da bu sürece katkı sağlaması gerekmektedir (Applegate vd., 2014, s. 200). Hem ailede hem çevresinde hem de okulda okuma etkinliklerine katılan çocuklarda okuma alışkanlığı kazandırılmış olur. Burada ailelerin ve çevrenin okuma bilinci kazandırılmasında ne kadar etkili olduğu ön plana çıkmaktadır. Janes (2008, s. 99) tarafından yapılan araştırma da bunu destekler niteliktedir. Zira yaptığı araştırmada, okuma 
konusunda bilgilendirilmiş ailelerin çocuklarının kitaba karşı ilgi gösterdikleri ortaya çıkmıştır. Hem ailelerin bilinçlendirilebilmesi hem de çocukların okuma alışkanlığının kazanabilmesi için bireylerin öncelikle okumanın önemini kavraması ve okumanın hayatına sunduğu katkılara inanması gerekmektedir (Bamberger, 1990, s. 39). İnsanın doğuştan getirdiği ilgi ve ihtiyaçları ile başlayan bu süreç, okuma eyleminin sağladığı yararları kavrama ile devam eder ve okuma alışkanlığına dönüşür (Bamberger, 1990, s. 44).

Toplumların çağdaş olabilmesinin temel unsurlarından biri okuyan bireylere sahip olmasıdır. Çünkü üretken, sorgulayan, yapıcı, eleştirel düşünme becerisine sahip ve özgürlükçü bireylerin bir toplumda yer alabilmesi o toplumun okuma alışkanlığını kazanabilmesine bağlıdır (Gömleksiz, 2004, s. 2). Phillip (2020, s. 7-8) okumanın yararlarını ikiye ayırmıştır. Bunlardan ilki okumanın insanlara mantıksal bir gelişim kazandırması; ikincisi ise okuma alışkanlığı edinmiş toplum üyelerinin yaşadıkları topluma kazandıracakları ekonomik gelişmedir. Mantıksal gelişim kazanmış ve sisteme katkıda bulunan bireyler de çağdaş toplumların ortaya çıkmasını sağlayacaktır. Bamberger (1990, s. 18) de işlevsel okuryazarlık seviyesine ulaşmış bireylerin kendilerine ve topluma yararları olacağından bahsetmektedir.

Okumanın tanımlarına bakıldığında belli bir amaç doğrultusunda gerçekleştirilen eylem olarak nitelendirildiği görülebilmektedir. Toplumların kültürel, sosyal, ekonomik özelliklerine göre şekil alabilen okuma amaçları, bireyler tarafından benimsenirse ve bireyler kendilerine bir amaç edinirlerse okuma alışkanlığının kazanılması ve devam ettirilmesi çok daha mümkün hâle gelebilecektir. Okumanın amaçları şu başlılarla ele alınabilir:

- Boş zamanları değerlendirmek, keyif almak için okuma,

- Bilgi edinmek için okuma,

- Mesleki gelişimi sağlamak için okuma,

- Sayılan üç okuma amacıyla farklı kombinasyonlar oluşturularak yapılan okuma

(Ogunrombi ve Adio, 1995, s. 50). Örneğin; keyif alarak bilgi edinmek için okuma $v b$.

Bireylerin okuma amaçlarını belirlemeleri, onların okumaya karşı itici güçleri olacaktır. Amacı belli olan birey o amacını gerçekleştirmek için çaba harcar, zaman ayırır ve emeline ulaşır. Okuma amacı belli olan birey de hedeflerine ulaşabilmek için bir çaba içine girecektir.

Okuma alışkanlığı kazanmış ve düzenli olarak okuyan bireylere okuma, çeşitli yararlar sağlamaktadır. Yapılan birçok araştırmada okumanın bireylere sağladığ1 katkılar belirlenmeye çalışılmıştır (Adalı, 2010; Akçamete, 1991; Güneş, 1999; Kartal ve Çağlar Özteke, 2010; Kolers, 1973; Sever, 2004). Bu yararlardan bazılarını ise şöyle sıralamak mümkündür: kişinin iç dünyasını zenginleştirme, olaylara bakış açısını genişletme, hoşgörülü olmayı sağlama, önyargıların yıkılmasını sağlama, beğeni düzeyini artırma, düşünme becerisi kazandırma, yaratıcılı̆̆ı ve değerlendirme becerisini geliştirme (Koç ve Müftüoğlu 2008, s. 62).

İnsanların okuma alışkanlığını kazanmasıyla birlikte çeşitli okuyucu tipleri de ortaya çıkmaktadır. Okuyucu tiplerinin sınıflandırılmasında en yaygın kabul edilen ölçüt, Amerikan Kütüphane Derneği (American Library Association-ALA) tarafından yapılan sınıflandırmadır. Bu sınıflandırma şu şekilde verilebilir:

-Zayıf okuyucu: Yılda 1-5 arası kitap okuyan 
- Orta düzey okuyucu: Yılda 6-11 arası kitap okuyan

- Güçlü okuyucu: Yılda 12 ve daha fazla kitap okuyan (Yılmaz, 2004, s. 116).

Yapılan sınıflandırmadan hareketle Türkiye'nin okuyucu tiplerini de ortaya çıkarmak mümkündür. Türkiye Okuma Kültürü Haritası Projesi (2011) verileri incelendiğinde Türkiye'deki 7-14 yaş arası bireylerin yılda ortalama 12 kitap, kadınların ortalama 7.3 kitap, erkeklerin ortalama 7.1 kitap, öğrencilerin yılda ortalama 11.1 kitap, seçici ve düzenli okuyanların ise yılda ortalama 14.5 kitap okuduğu görülecektir. Bu verilerden hareketle Türkiye'de sadece çocukların ve düzenli okuyanların güçlü okuyucu tipinde oldukları yorumunu yapmak mümkün olacaktır.

\section{Araştırmanın Amacı ve Önemi}

Üniversite öğrencilerinin okuma alışkanlıkları ve okur profillerini ortaya çıkarmaya yönelik alanyazında birçok araştırma mevcuttur. Ancak bu araştırmalar genellikle bölüm, fakülte veya sınırlı sayıda üniversite dikkate alınarak yapılmıştır (Demir, 2015; Gömleksiz, 2004; Keklik ve Çakmakçı, 2013; Kolaç, 2007; Kurulgan ve Çekerol, 2008; Kuş ve Türkyılmaz, 2010; Odabaş vd., 2008; Saracaloğlu vd., 2009; Şengül Bircan, 2017; Yalman vd., 2015; Yıldız vd., 2015; Yılmaz vd., 2009).

Araştırmada ise çok sayıda üniversitenin ve fakültenin öğrencileri kapsama dâhil edilmiştir. Geniş kapsamlı bu araştırmayla üniversite öğrencilerinin kitap okuma profillerinin ortaya çıkarılmasının bundan sonra yapılacak faaliyetlere yol gösterici bir niteliğe sahip olacağı düşünülmektedir. Üniversite öğrencilerinin kitap tercihleri, konu tercihleri, yılda kaç kitap okudukları, kitaplarını nasıl temin ettikleri gibi hususların bilinmesi, onlara doğru kitapları sunma ve onları kitap okumaya yönlendirmede önemli noktalar olarak görülmektedir. Ayrıca farklı bölgeler, farklı üniversiteler ve farklı fakültelerde eğitim alan öğrencilerin okuyucu profillerini çıkarmaya yönelik araştırmaların olmaması yönüyle araştırmanın alanyazına katkı sunacağı da düşünülmektedir.

$\mathrm{Bu}$ araştırmanın amacl; Türkiye'de üniversite okuyan öğrencilerin okuyucu profillerini ortaya çıkarmaktır. Araştırmanın bu genel amacı doğrultusunda aşağıdaki sorulara cevap aranmıştır:

- Üniversite öğrencilerinin düzenli olarak kitap okuma durumu nasıldır?

- Üniversite öğrencileri yerli eserleri mi yoksa yabancı eserleri mi daha çok tercih etmektedir?

- Üniversite öğrencilerinin tercih ettiği kitap türleri nelerdir?

- Üniversite öğrencilerinin okudukları kitapların konusu nedir?

- Kitap seçimini etkileyen unsurlar nelerdir?

- Üniversite öğrencilerinin sahip olduğu kitap sayısı kaçtır?

- Üniversite öğrencilerinin son bir yılda okuduğu kitap sayısı kaçtır?

\section{YÖNTEM}

\section{Araştırma Modeli}

Üniversite öğrencilerinin kitap okuma profillerinin belirlenmesine yönelik hazırlanan araştırma, nicel araştırma yöntemlerinden biri olan tarama araştırması olarak modellenmiştir. 
Tarama araştırmaları; geniş kitlelerin görüşlerini, ilgi, beceri, yetenek veya tutum gibi özelliklerini ortaya çıkarmak amacıyla yapılan araştırmalardır ve sosyal bilimlerde en çok tercih edilen araştırma tasarımlarından biridir (Büyüköztürk, vd., 2018, s. 184; Kelley vd., 2003, s. 261). Tarama araştırmalarında genellikle "ne, ne kadar, ne zaman, nasıl, hangi sıklıkta, nerede" gibi sorulara cevap aranır (Wellington, 2006, s. 31-32). Araştırmada da üniversite öğrencilerinin kitap okuma profillerini ortaya çıkarabilmek adına; "ne kadar kitap okudukları, hangi türleri okudukları, kitaplarını nasıl temin ettikleri, kaç kitaba sahip oldukları, hangi konuları içeren kitapları tercih ettikleri" gibi sorulara cevap aranmıştır. Araştırma süreci Şekil 1'deki gibi gerçekleşmiştir:

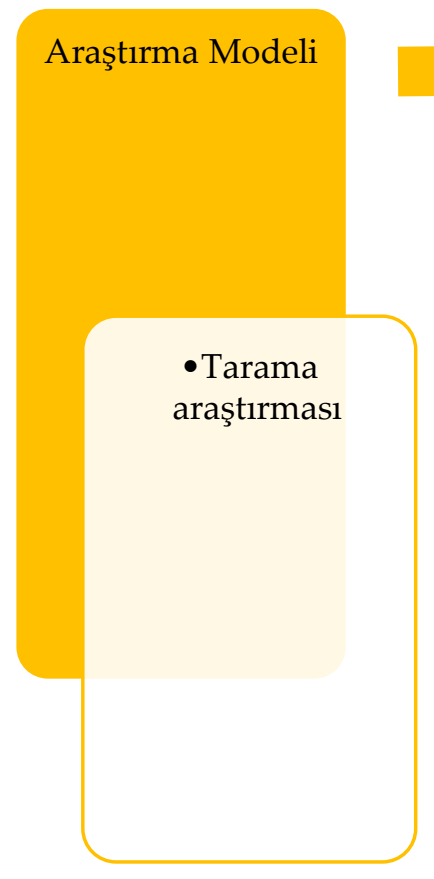

Evren ve Örneklem

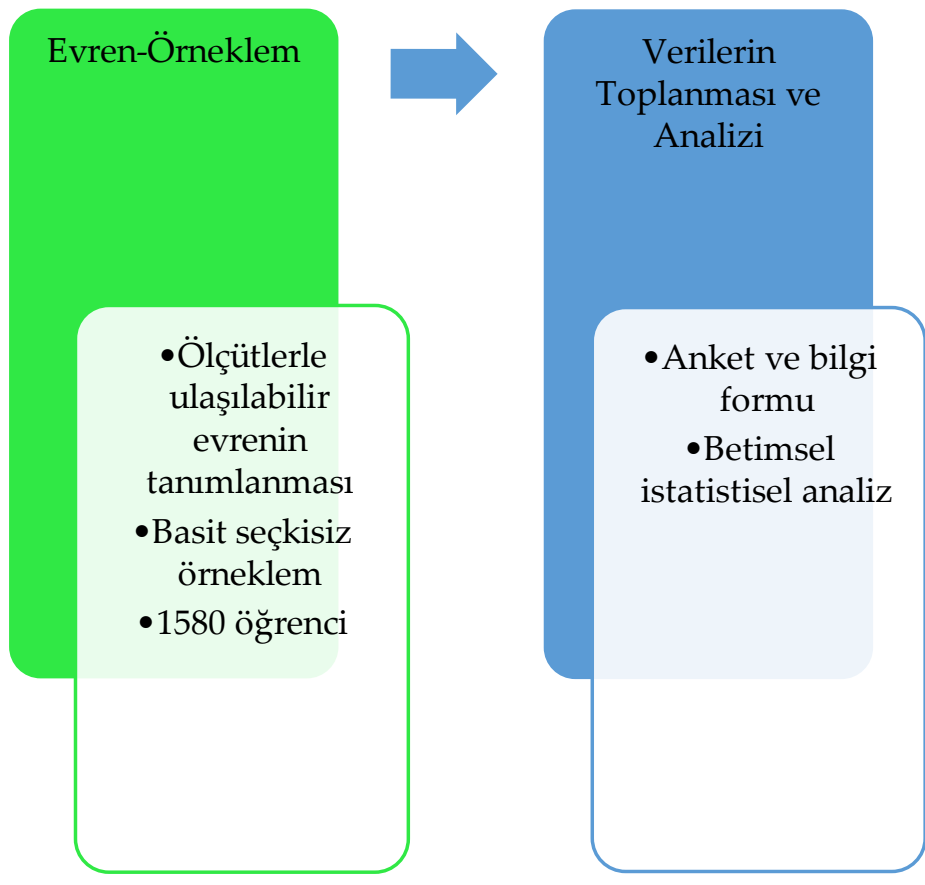

Şekil 1. Araştırma Süreci Diyagramı

$\mathrm{Bu}$ araştırmanın evreninin sınırlarını çizmek ve ulaşılabilir evreni tanımlamak için belirli ölçütler kullanılmıştır. Bu bağlamda devlet üniversitelerinde lisans düzeyinde örgün eğitim alan öğrencilerin tamamı bu araştırmanın ulaşılabilir evrenini oluşturmaktadır. Buna göre araştırmanın evreninin 1.969.844 (YÖK, 2020) olduğu tespit edilmiştir. Araştırmanın örnekleminde ise basit seçkisiz örneklem alma tekniği kullanılmıştır. Örneklemin temsil derecesinin geçerliğini sağlayabilmek için Krejcie ve Morgan (1970, s. 607) tarafindan ortaya konulan formül kullanılmıştır. Bu formüle göre \%95’lik güven düzeyi için 1.969 .844 kişilik evrende 384 kişilik örneklemin yeterli olacağı ortaya çıkmıştır. Fakat araştırmada gönüllülük esasının olması ve anketin eksik, fazla veya yanlış doldurulabileceği gibi ihtimallerden dolayı örneklem büyüklüğü yüksek tutulmuştur. Bu bağlamda araştırmada uygulanabilirlik ve ekonomiklik ilkesi göz önüne alınarak seçkisiz olarak 37 devlet üniversitesi belirlenmiştir. Ancak uygulama izni alınabilen ve izin alınsa da araştırmaya katılmaya gönüllü olan 19 üniversitenin 17 farklı fakültesinde eğitim alan 1706 öğrenciden bu araştırma için veriler toplanmıştır. Toplanan formların 126'sı fazla işaretleme, eksik işaretleme, kişisel bilgi formunu doldurmama gibi nedenlerden dolayı çıkarılmış ve sonuç olarak 1580 öğrenci bu araştırmanın örneklemini oluşturmuştur. Örneklemde yer alan 
üniversite öğrencilerinin demografik özelliklerine ilişkin veriler Tablo 1, Tablo 2 ve Tablo 3'te verilmiştir:

Tablo 1. Araştırma Grubunun Cinsiyet, Yaş ve Sınıf Düzeylerine Göre Dağılımı

\begin{tabular}{|c|c|c|c|}
\hline & & $f$ & $\%$ \\
\hline \multirow{3}{*}{ 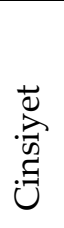 } & Erkek & 539 & 34.1 \\
\hline & Kadın & 1041 & 65.9 \\
\hline & Toplam & 1580 & 100 \\
\hline \multirow{6}{*}{$\overbrace{}^{\pi}$} & $18-20$ & 1037 & 65.6 \\
\hline & $21-23$ & 391 & 24.7 \\
\hline & $24-26$ & 100 & 6.3 \\
\hline & 26 ve üstü & 52 & 3.3 \\
\hline & Toplam & 1580 & 100 \\
\hline & 1. sinif & 700 & 44.3 \\
\hline \multirow{5}{*}{$\begin{array}{l}\vec{\Xi} \\
\text { जี }\end{array}$} & 2. sinif & 469 & 29.7 \\
\hline & 3. sinif & 215 & 13.6 \\
\hline & 4. sinif & 176 & 11.1 \\
\hline & 5. sinif & 20 & 1.3 \\
\hline & Toplam & 1580 & 100 \\
\hline
\end{tabular}

Tablo 2. Araştırma Grubunun Eğitim Aldığı Fakülteler

\begin{tabular}{lcc}
\hline Fakültte & $f$ & \% \\
\hline Gemi İnşaatı ve Deniz Bilimleri Fakültesi & 52 & 3.3 \\
Diş Hekimliği Fakültesi & 90 & 5.7 \\
Eczacılık Fakültesi & 46 & 2.9 \\
Eğitim Fakültesi & 274 & 17.3 \\
Fen Edebiyat Fakültesi & 177 & 11.2 \\
Güzel Sanatlar ve Tasarım Fakültesi & 84 & 5.3 \\
Hukuk Fakültesi & 73 & 4.6 \\
İktisadi ve İdari Bilimler Fakültesi & 68 & 4.3 \\
İlahiyat Fakültesi & 104 & 6.6 \\
İletişim Fakültesi & 89 & 5.6 \\
Mühendislik-Mimarlık Fakültesi & 96 & 6.1 \\
Sağlık Bilimleri Fakültesi & 87 & 5.5 \\
Spor Bilimleri Fakültesi/BESYO & 35 & 2.2 \\
Teknoloji Fakültesi & 79 & 5 \\
Tıp Fakültesi & 62 & 3.9 \\
Turizm Fakültesi & 100 & 6.3 \\
Ziraat Fakültesi & 64 & 4.1 \\
Toplam & $\mathbf{1 5 8 0}$ & $\mathbf{1 0 0}$ \\
\hline
\end{tabular}


Tablo 3. Araştırma Grubunun Eğitim Aldığı Üniversiteler ve Yaşadıkları Bölgeler

\begin{tabular}{|c|c|c|c|}
\hline Bölge & Üniversite & $f$ & $\%$ \\
\hline \multirow{4}{*}{$\begin{array}{l}\mathbb{\sigma} \\
\tilde{\Xi} \\
\stackrel{\Xi}{\pi}\end{array}$} & Marmara Üniversitesi & 20 & 1.3 \\
\hline & İstanbul Medeniyet Üniversitesi & 60 & 3.8 \\
\hline & Yıldız Teknik Üniversitesi & 91 & 5.8 \\
\hline & Toplam & 171 & 10.9 \\
\hline \multirow{3}{*}{$\underset{80}{\infty}$} & İzmir Demokrasi Üniversitesi & 69 & 4.4 \\
\hline & Uşak Üniversitesi & 85 & 5.4 \\
\hline & Toplam & 154 & 9.8 \\
\hline \multirow{5}{*}{ 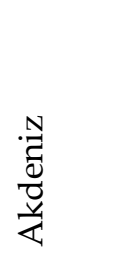 } & Hatay Mustafa Kemal & 97 & 6.1 \\
\hline & Üniversitesi & & \\
\hline & Isparta Uygulamalı Bilimler & 25 & 1.6 \\
\hline & Üniversitesi & & \\
\hline & Toplam & 122 & 7.7 \\
\hline \multirow{3}{*}{ 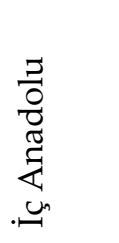 } & Hacettepe Üniversitesi & 78 & 4.9 \\
\hline & Hacı Bektaş Veli Üniversitesi & 94 & 5.9 \\
\hline & Toplam & 172 & 10.8 \\
\hline \multirow{3}{*}{ 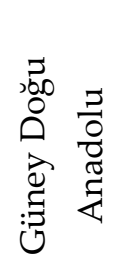 } & Adıyaman Üniversitesi & 53 & 3.4 \\
\hline & Kilis 7 Aralık Üniversitesi & 161 & 10.2 \\
\hline & Toplam & 214 & 13.6 \\
\hline \multirow{6}{*}{ 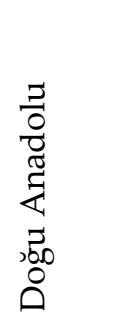 } & Bingöl Üniversitesi & 98 & 6.2 \\
\hline & Frrat Üniversitesi & 123 & 7.8 \\
\hline & İnönü Üniversitesi & 97 & 6.1 \\
\hline & Erzincan Binali Yıldırım & 68 & 4.3 \\
\hline & Üniversitesi & & \\
\hline & Toplam & 386 & 24.4 \\
\hline \multirow{6}{*}{ 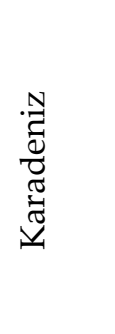 } & Abant İzzet Baysal Üniversitesi & 132 & 8.3 \\
\hline & Amasya Üniversitesi & 101 & 6.4 \\
\hline & Karadeniz Teknik Üniversitesi & 92 & 5.8 \\
\hline & Trabzon Teknik Üniversitesi & 36 & 2.3 \\
\hline & Toplam & 361 & 22.8 \\
\hline & Toplam & 1580 & 100 \\
\hline
\end{tabular}

\section{Veri Toplama Araçları}

Üniversite öğrencilerinin kitap okuma profillerini belirlemek amaciyla hazırlanan araştırmada, öğrencilerin kişisel bilgilerini toplayabilmek amacıyla araştırmacı tarafından oluşturulan Kişisel Bilgi Formu kullanılmıştır. Bu form öğrencilerin cinsiyeti, yaşı, üniversitesi, fakültesi, yaşadığı bölge ve sınıf düzeyi gibi bilgileri içermektedir.

Öğrencilerin kitap okuma profillerini belirleyebilmek için de yine araştırmacı tarafından oluşturulmuş Kitap Okuma Profilleri Anketi kullanılmıştır. Anketler; insanların hayat tarzlarını, 
davranış biçimlerini, inanç veya tutumlarını betimleyebilmek amacıyla hazırlanmış materyallerdir (Thomas, 1998, s. 98). Diğer veri toplama araçlarına göre farklı bölgelerden çok daha büyük gruplara ulaşma imkânı sağlaması ve daha az maliyetli olması gibi durumlardan dolayı anketler tercih edilir (Büyüköztürk vd., 2018, s. 129). Araştırmada kullanılmak üzere 23 maddelik bir anket hazırlanmış ve uzman görüşü alınması amacıyla 8 akademisyene (1 ölçme değerlendirme uzmanı, 4 Türkçe eğitimi uzmanı, 3 yeni Türk edebiyatı uzmanı) gönderilmiştir. Uzmanlardan alınan dönütler neticesinde anketteki maddelerin kapsam geçerlik oranları hesaplanmıştır. Kapsam geçerlik oranlarının istatiksel olarak anlamlılığını test etmek için hesaplama kolaylığı açısından $\alpha=.05$ anlamlılık düzeyinde minimum değerleri tablo hâline getirilmiştir (Vneziano ve Hooper 1997'den akt. Yurdugül, 2005, s. 2). Bu bağlamda uzman sayısına ilişkin minimum değerler Tablo 4'te, Kitap Okuma Profilleri Anketi için elde edilen kapsam geçerlik oranları ise Tablo 5'te sunulmuştur:

Tablo 4. Kapsam Geçerlik Oranları İçin Minimum Değerler $(\alpha=.05)$

\begin{tabular}{|c|c|c|c|}
\hline $\begin{array}{l}\text { Uzman } \\
\text { Sayısı }\end{array}$ & $\begin{array}{c}\text { Minimum } \\
\text { Değer }\end{array}$ & $\begin{array}{c}\text { Uzman } \\
\text { Sayisı }\end{array}$ & $\begin{array}{l}\text { Minimum } \\
\text { Değer }\end{array}$ \\
\hline 5 & .99 & 13 & 0.54 \\
\hline 6 & .99 & 14 & 0.51 \\
\hline 7 & .99 & 15 & 0.49 \\
\hline 8 & .78 & 16 & 0.42 \\
\hline 9 & .75 & 17 & 0.37 \\
\hline 10 & .62 & 18 & 0.33 \\
\hline 11 & .59 & 19 & 0.31 \\
\hline 12 & .56 & 20 & 0.29 \\
\hline
\end{tabular}

Tablo 4'te uzman sayılarına göre maddelerin kapsam geçerlik oranlarının belirlenebilmesi için sahip olmaları gereken minimum değerler gösterilmiştir. Bu araştırmada değerlendirme amacıyla 8 uzmana başvurulduğu için maddelerin sahip olması gereken minimum değer $.78^{\prime}$ dir.

Tablo 5. Kitap Okuma Profilleri anketi ve Kapsam Geçerlik Değerleri

\begin{tabular}{lcccc}
\hline Madde No & Gerekli & Düzeltilmeli & Çıarılmalı & KGO \\
\hline Madde 1 & 8 & 0 & 0 & 1 \\
Madde 2 & 8 & 0 & 0 & 1 \\
Madde 3 & 6 & 2 & 0 & .5 \\
Madde 4 & 6 & 2 & 0 & .5 \\
Madde 5 & 8 & 0 & 0 & 1 \\
Madde 6 & 8 & 0 & 0 & 1 \\
Madde 7 & 8 & 0 & 0 & 1 \\
Madde 8 & 8 & 0 & 0 & 1 \\
Madde 9 & 8 & 0 & 0 & 1 \\
Madde 10 & 8 & 0 & 0 & 1 \\
Madde 11 & 8 & 0 & 0 & 1 \\
Madde 12 & 7 & 1 & 0 & .75
\end{tabular}




\begin{tabular}{llllc} 
Madde 13 & 8 & 0 & 0 & 1 \\
Madde 14 & 5 & 3 & 0 & .25 \\
Madde 15 & 8 & 0 & 0 & 1 \\
Madde 16 & 8 & 0 & 0 & 1 \\
Madde 17 & 8 & 0 & 0 & 1 \\
Madde 18 & 1 & 3 & 4 & -.75 \\
Madde 19 & 6 & 2 & 0 & .5 \\
Madde 20 & 6 & 2 & 0 & .5 \\
Madde 21 & 6 & 2 & 0 & .5 \\
Madde 22 & 1 & 4 & 3 & -.75 \\
Madde 23 & 4 & 2 & 2 & 0 \\
\hline
\end{tabular}

KGO değerleri hesaplandıktan sonra Kapsam Geçerlik İndeksi (KGİ) de hesaplanmıştır. KGİ, $\alpha=.05$ düzeyinde anlamlı olan ve nihai forma alınacak maddelerin toplam KGO ortalamaları üzerinden elde edilir. KGİ değerleri alt boyutlar için geçerli olup, her bir alt boyut için, alt boyutta yer alan maddeler dikkate alınarak elde edilmektedir (Yurdugül, 2005, s. 2). Araştırmada kullanılan anketin kapsam geçerlik indeksi 1.00 olarak hesaplanmıştır.

23 madde olarak tasarlanan anketten uzman görüşleri doğrultusunda kapsam geçerlikleri yeterli değeri taşımayan 10 madde çıkarılmış ve 13 madde olarak belirlenen ankete son hâli verilmiştir.

\section{Verilerin Analizi}

Araştırmada, Kitap Okuma Profilleri Anketi ile elde edilen verilerin çözümlenmesinde betimsel istatistiksel analiz yöntemleri kullanılmış ve elde edilen verilerin yüzde (\%) ve frekans (f) değerleri verilmiştir. SPSS paket programı aracılığıyla yapılan analizlerle öğrencilerin kitap okuma profilleri ortaya çıkarılmıştır. Tüm bulgular, cinsiyet ve fakülte değişkenine göre de değerlendirilmiş ve diğer bulguları desteklemek amacıyla yorum kısmında bunların da frekans ve yüzdeleri verilmiştir. Böylece öğrencilerin kitap okuma profilleri, cinsiyet ve fakültelere göre de yorumlanmıştır.

\section{BULGULAR}

Araştırmanın bu bölümünde, katılımcıların kitap okuma profillerini ortaya çıkarmaya yönelik uygulanan anket verileri paylaşılmıştır. Verilerin frekans ve yüzde değerleri verilmiş ve bunların yorumları yapılmıştır.

Katılımcıların düzenli kitap okuyup okumadıklarına dair bulgular Şekil 2'de verilmiştir: 


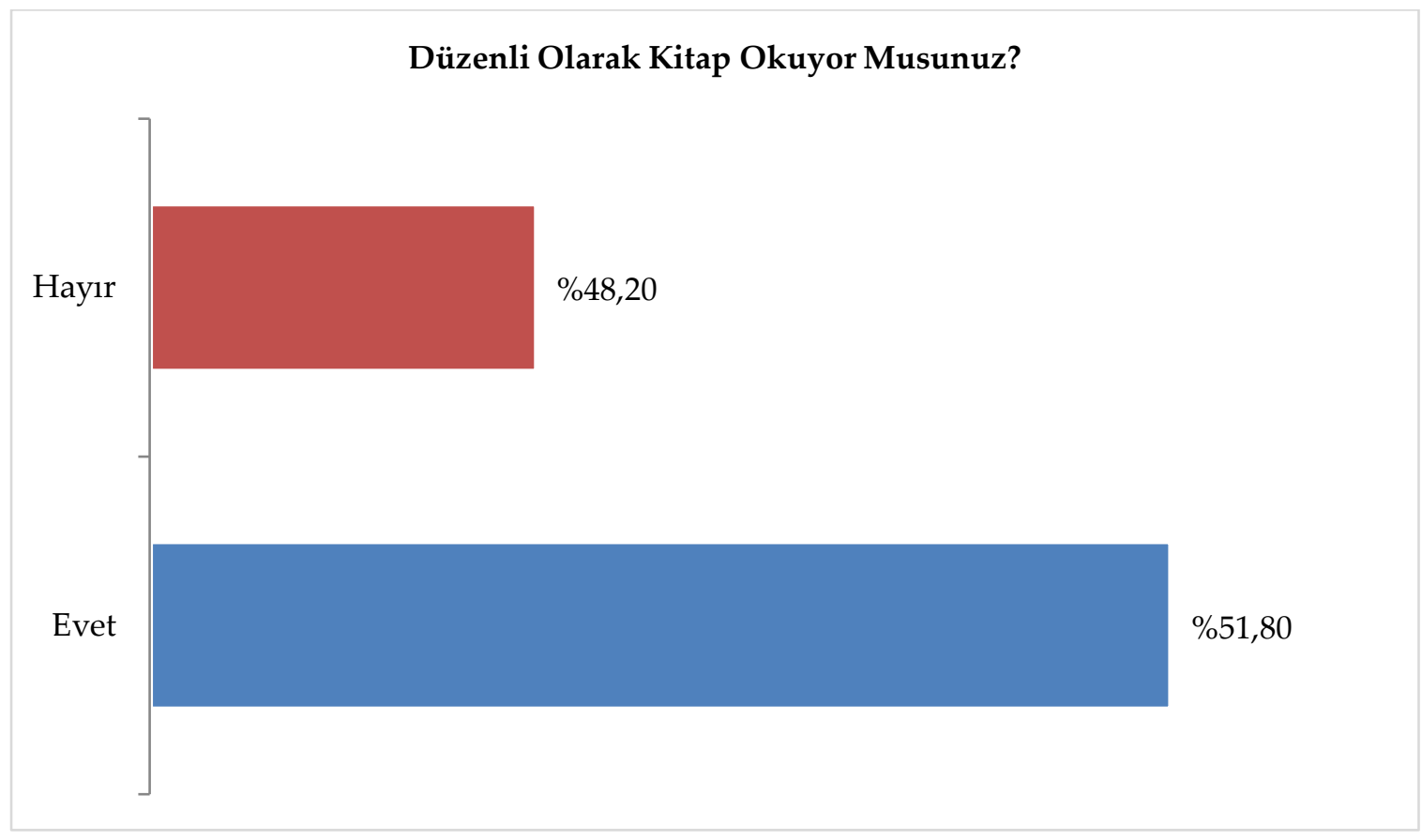

Şekil 2.Katılımcıların Düzenli Kitap Okuyup Okumadıklarına Dair Bulgular

Şekil 2'de öğrencilerin düzenli olarak kitap okuyup okumadıklarına dair veriler sunulmuştur. Buna göre öğrencilerin 819’u (\%51.8) düzenli olarak kitap okuduklarını belirtirken 761'i (48.2) düzenli olarak kitap okumadıklarını bildirmişlerdir. Veriler üzerinde yapılan karşılaştırma analizi sonucunda erkek ve kadınların karşılaştırması da yapılmıştır. Bu analize göre erkeklerin \%41.6'sı düzenli olarak kitap okuduklarını, \%58.4'ü ise okumadıklarını belirtmişlerdir. Kadınlarda ise bu durum düzenli olarak okuyorum diyenlerin daha fazla olduğunu göstermektedir. Düzenli olarak kitap okuduğunu düşünen kadın oranı \%57.2 iken okumadıklarını düşünen kadın oranı ise 42.8'dir. Benzer bir karşılaştırma fakülteler arasında da yapılmıştır. Elde edilen verilere göre hukuk fakültesinde okuyan öğrencilerin $\% 69.9^{\prime}$ u düzenli olarak kitap okuduklarını belirtmişlerdir. Bunu tıp fakültesi öğrencileri (\%64.5) takip etmektedir. Düzenli olarak kitap okuduğunu bildiren en az öğrenci ise deniz bilimleri/gemi inşaatı ve deniz bilimleri fakültesinde (\%28.8) eğitim almaktadır. Bu sonuçlara göre üniversite öğrencilerimizin çoğu, kadınlarda daha fazla olmakla beraber, düzenli olarak kitap okuduklarını düşünmektedir.

Kitap okuma alışkanlığını kazanmada etkili olan unsurların neler olduğuna dair öğrenci görüşlerine Şekil 3’te yer verilmiştir: 


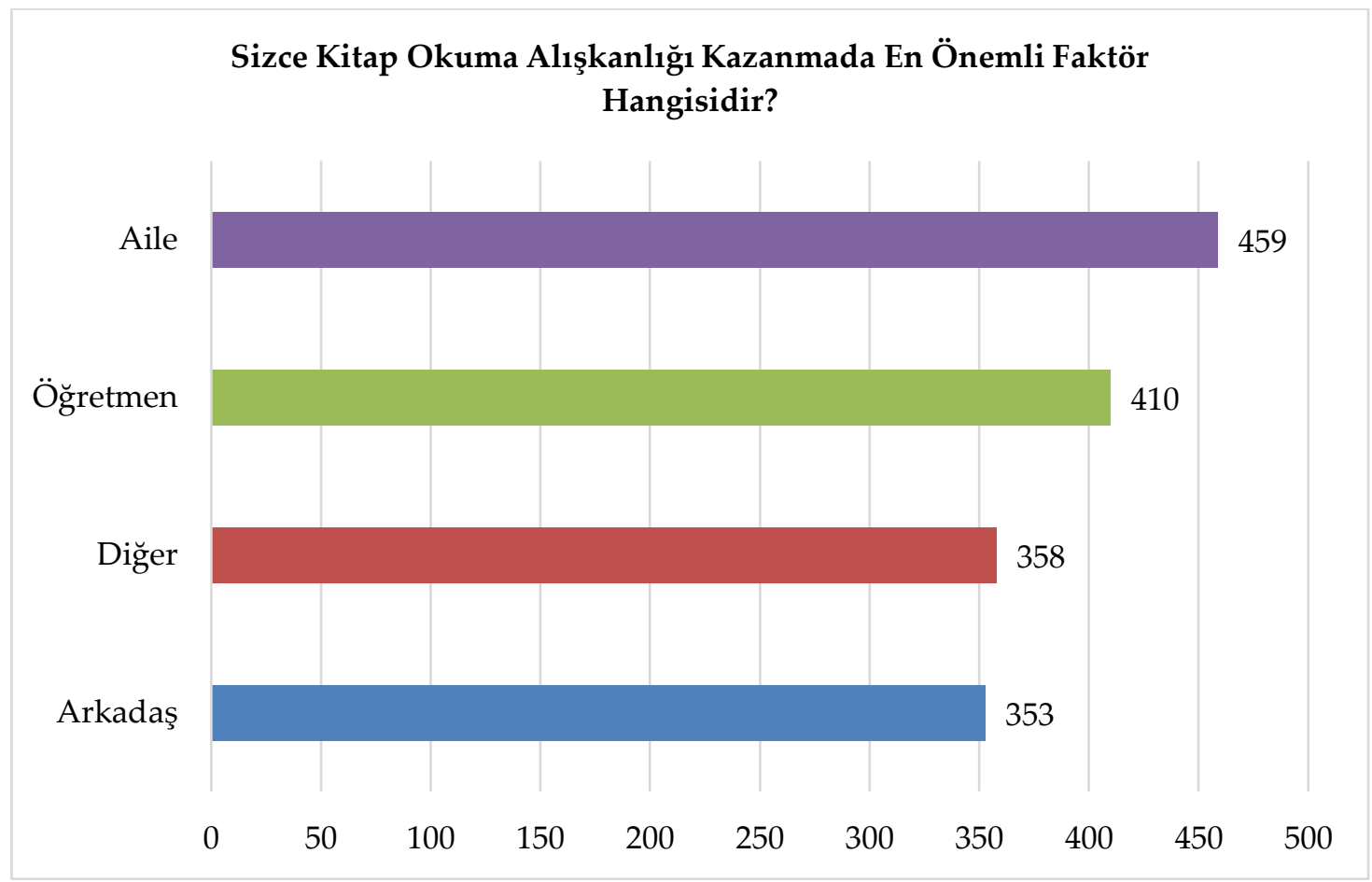

Şekil 3. Okuma Alışkanlığını Kazanmada Etkili Olan Unsurlara İlişkin Veriler

Şekil 3'te öğrencilerin kitap okuma alışkanlığını kazanmada en önemli faktörün kim/ne olduğuna yönelik görüşlerine yer verilmiştir. Buna göre öğrencilerin 459'u (\%29.1) aile cevabını vermiştir. Bunu sırasıyla öğretmen (\%25.9), diğer (\%22.7) ve arkadaş (\%22.3) takip etmektedir. Diğer cevabını verenlerin büyük kısmı ise $(\mathrm{f}=254)$ kitap okuma alışkanlığı kazanmada kişinin kendisinin etkili olduğunu belirtmişlerdir. Bu öğrenciler, merak ve ilgi gibi sebeplerle bireylerin kitap okumaya yöneldiğini ve bunun sonucunda da alışkanlık kazanıldığını bildirmişlerdir. Geri kalan kısım ise okul ve çevre gibi faktörlerin bu alışkanlığın kazanılmasında daha etkili olduğunu düşünmektedir.

Elde edilen bulgular kitap okuma alışkanlığında ailenin ve sonrasında da öğretmenin ne kadar önemli olduğunu göstermektedir. Burada özellikle ailelere büyük bir görevin düştüğü görülmektedir. Bu durumda, ailelerin bu konuda bilinçlendirilmesi ve çocuklara okuma alışkanlığının kazandırılmasında görevlerini yapmalarının sağlanması gerektiği yorumunu yapmak mümkün olacaktır.

Tercih edilen eserlerin yerli veya yabancı olmasına ilişkin bulgular Şekil 4'te verilmiştir: 
Tercih Ettiğiniz Eserler Daha Çok Hangisi Oluyor?

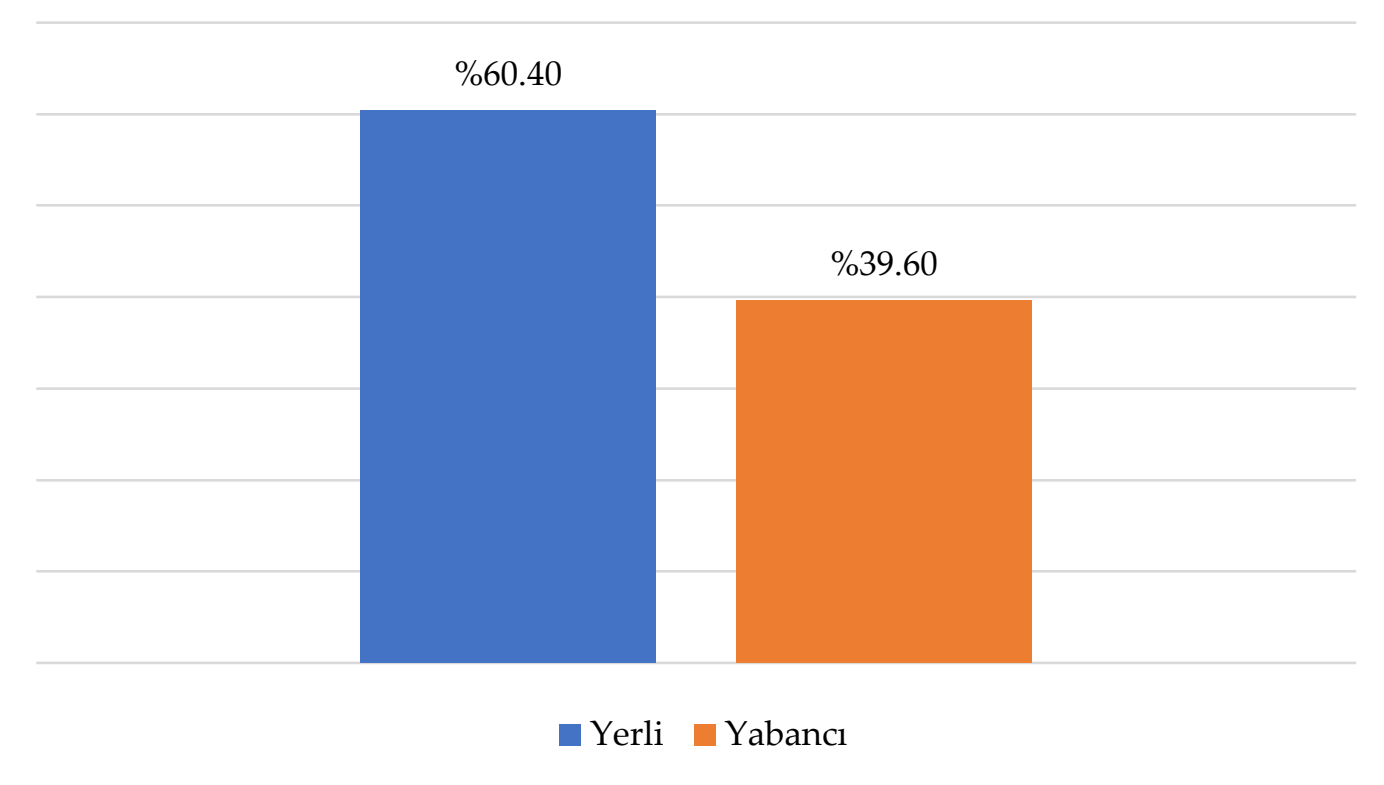

Şekil 4. Tercih Edilen Eserlerin Yerli veya Yabancı Olmasına İlişkin Bulgular

Şekil 4'te öğrencilerin tercih ettiği eserlerin yerli ya da yabancı olmasına ilişkin görüşlerine yer verilmiştir. Buna göre üniversite öğrencilerinin 954'ü (\%60.4) yerli eserleri daha çok tercih ettiklerini, 626'sı (\%39.6) ise yabancı eserleri tercih ettiklerini belirtmişlerdir. Erkek ve kadınların karşılaştırılmasında da benzer bir durum görülmektedir. Buna göre erkeklerin \%56.8'i yerli eserleri, kadınların ise \%62.2'si yine yerli eserleri tercih etmektedirler. Fakülteler arası karşılaştırmada ise yerli eserleri en fazla tercih edenlerin ilahiyat fakültelerinde okuyan öğrenciler (\%76) olduğu, yabancı eserleri en fazla tercih edenlerin de tıp fakültelerinde okuyan öğrenciler (\%62.9) olduğu tespit edilmiştir. Elde edilen bulgulara göre üniversite öğrencilerinin büyük kısmı yerli eserleri tercih etmektedir.

Elektronik aletler ve internetin kitap okuma amacıyla kullanımına ilişkin veriler Şekil 5 'te sunulmuştur: 


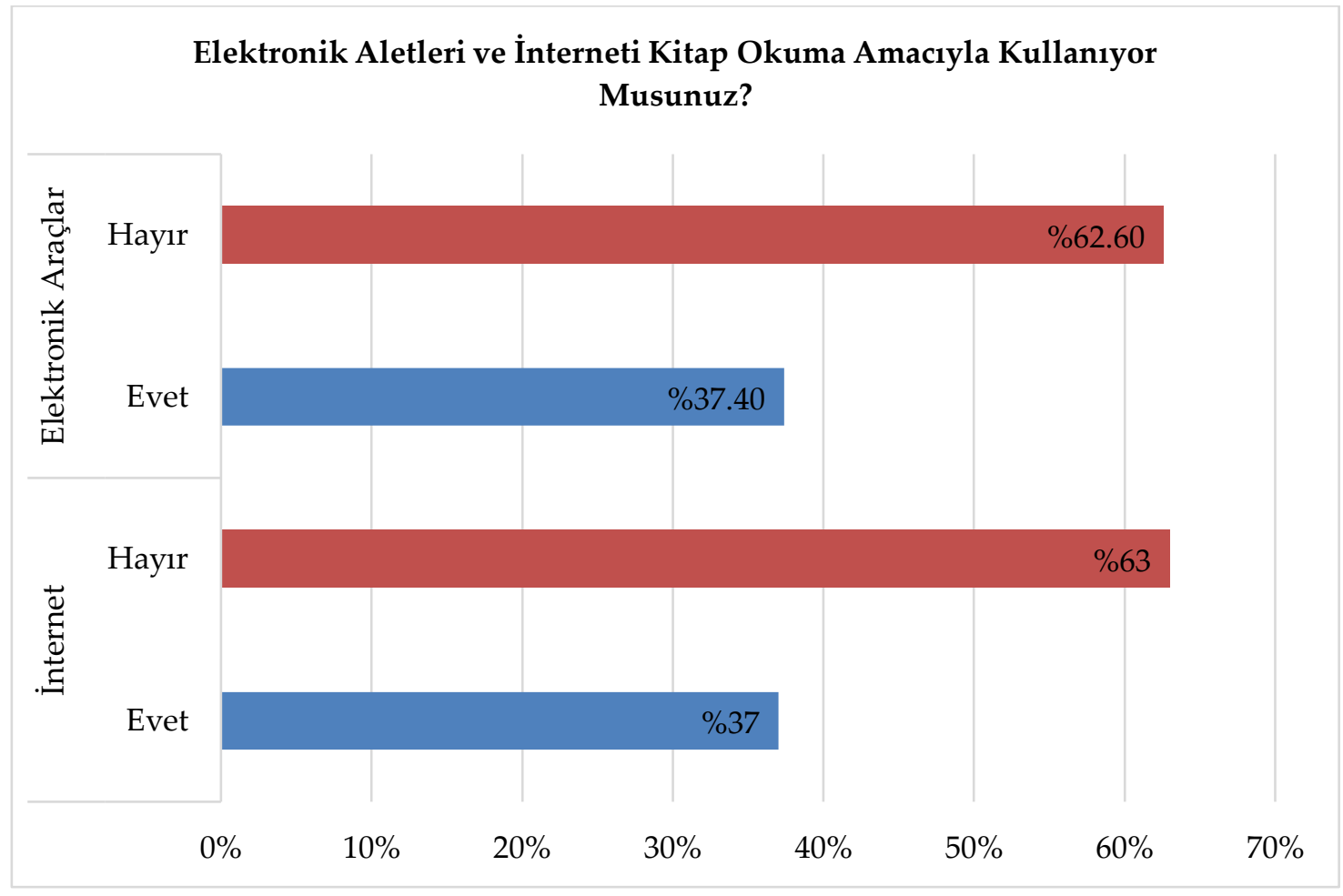

Şekil 5. Elektronik Aletler ve İnternetin Kitap Okuma Amacıyla Kullanımına İlişkin Veriler

Şekil 5'te öğrencilerin, elektronik araçları ve interneti kitap okuma amacıyla kullanıp kullanmadıklarına yönelik bulgular sunulmuştur. Elde edilen bulgulara göre öğrencilerin 591'i (\%37.40) elektronik araçları kitap okuma amacıyla kullandıklarını, 989'u (\%62.60) ise kullanmadıklarını belirtmişlerdir. Benzer durum internetin kullanımı için de geçerlidir. Buna göre öğrencilerin 584'ü (\%37) interneti kitap okuma amaciyla kullanırken 989'u (\%63) kullanmamaktadır. Hem cinsiyet hem de fakülteler için yapılan karşılaştırma sonucu da oldukça benzer bir sonuç vermektedir. Elektronik araçların ve internetin kitap okuma amacıyla kullanımı bu değişkenler için de genel bulgulara oldukça yakın çıkmaktadır.

Öğrencilerin derslerden arta kalan zamanlarında neler yaptıklarına ilişkin veriler incelendiğinde; 1144'ünün (\%72.5) vaktini internette geçirdiği görülmektedir. Bu durum öğrencilerin interneti yoğun olarak kullandığını fakat bunu kitap okuma amaciyla kullanmadıklarını göstermektedir.

Araştırma grubunun okuduğu kitap türüne ilişkin bulgular Şekil 6'da verilmiştir: 


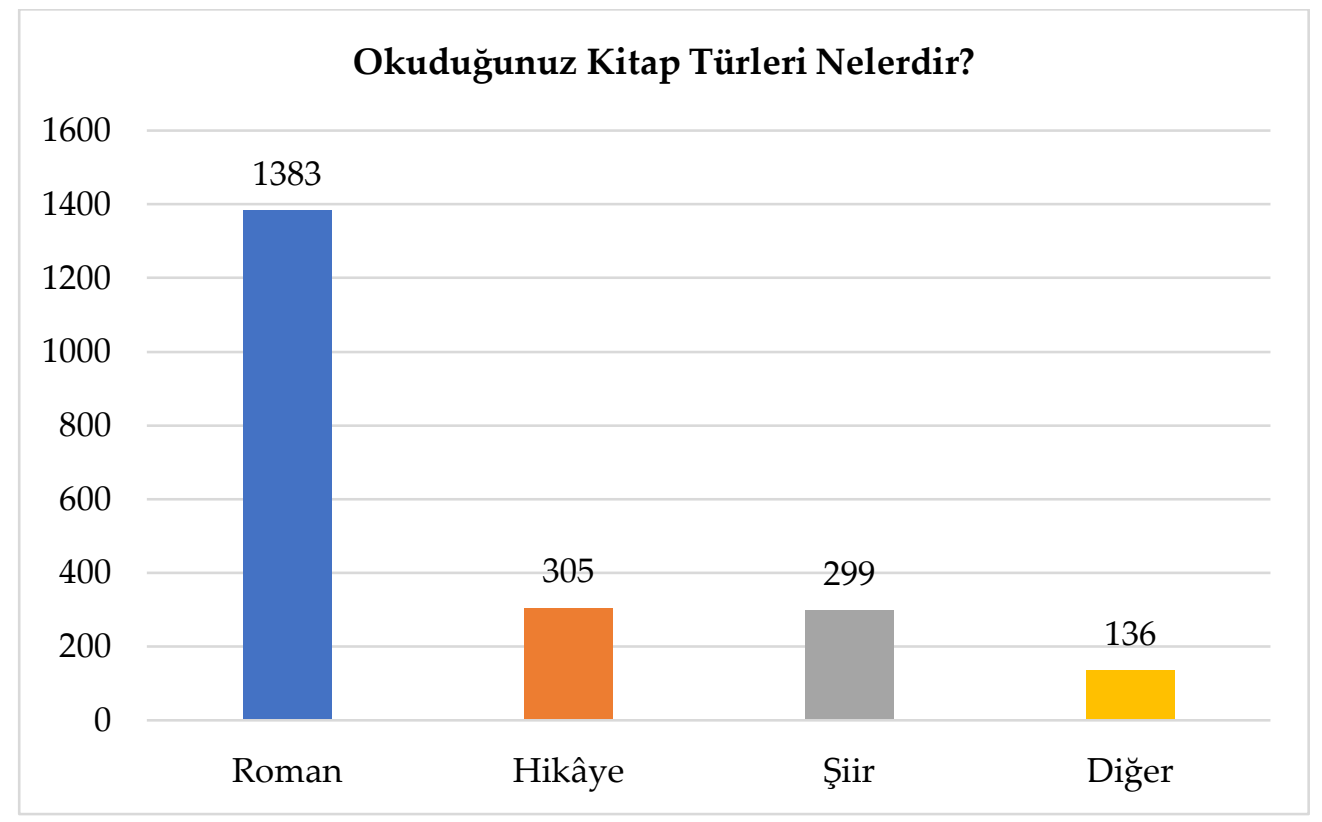

Şekil 6. Tercih Edilen Kitap Türüne İlişkin Veriler

Şekil 6'da öğrencilerin tercih ettikleri kitap türlerine yönelik veriler sunulmuştur. Madde çoklu yanıt olduğu için $f$ sayısı örneklem hacmini geçmektedir (Toplam $f=2123$ ). Bulgulara göre öğrenciler daha çok (\%65.1) roman okuduklarını bildirmişlerdir. Hikâye (\%14.4) ve şiir (\%14.1) kitaplarının okunma oranları ise birbirine oldukça yakındır. Diğer kitap türlerinin tercih oranı da \%6,4'tür. Diğger türlerde öğrenciler genellikle; biyografi/otobiyografi, deneme, günlük, çizgi roman, Kur'an-1 Kerim gibi kitapları okuduklarını belirtmişlerdir. Yapılan karşılaştırma analizi sonucunda erkeklerin \%80.3'ünün, kadınların ise \%91.3'ünün romanı tercih ettiği görülmüştür. Fakülteler arasında yapılan karşılaştırmada da benzer bir sonuç ortaya çıkmıştır. Tüm fakültelerde en fazla tercih edilen tür romandır.

Araştırma grubunun okuduğu kitapların konusuna ilişkin bulgular Şekil 7'de verilmiştir:

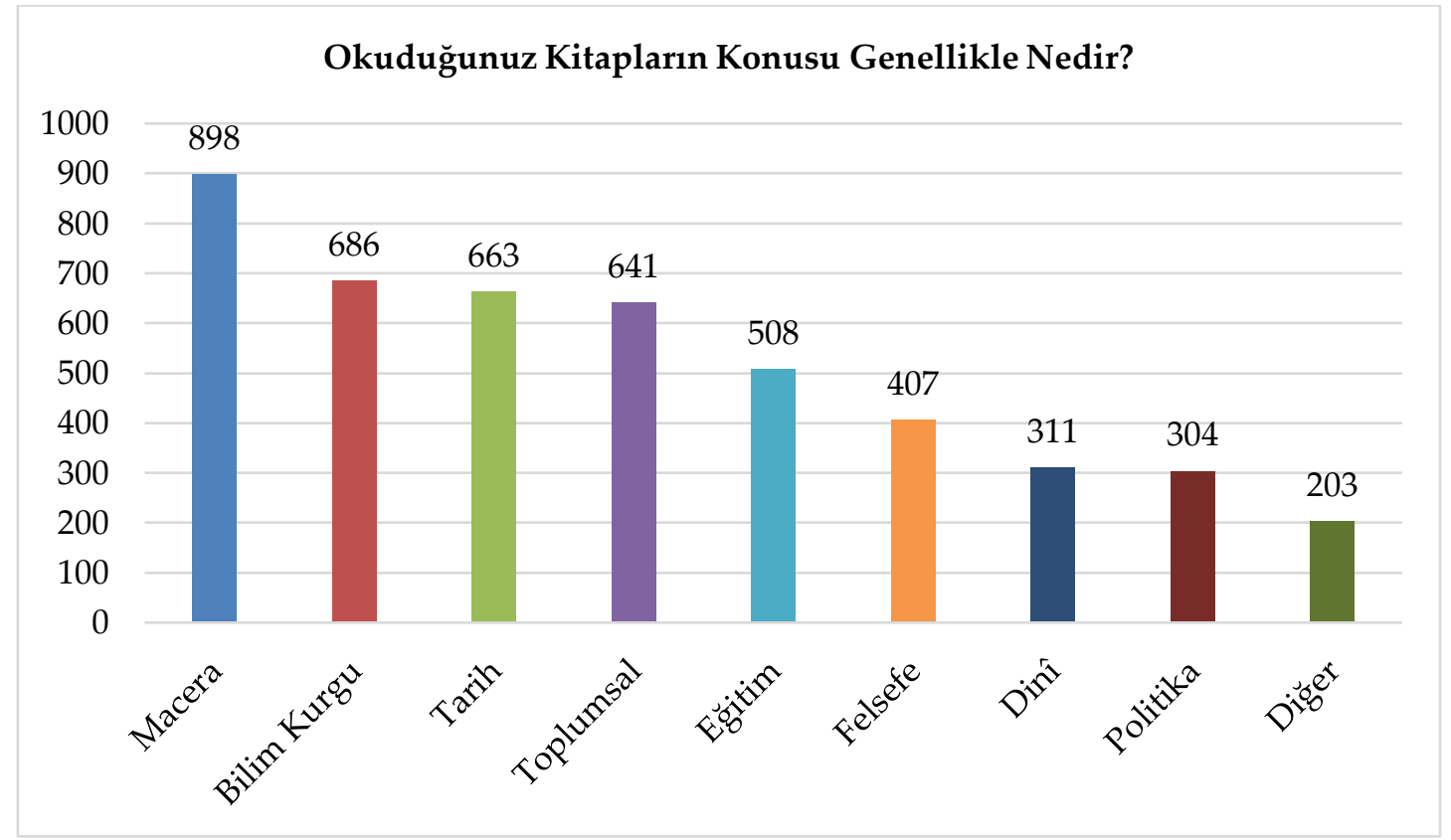

Şekil 7. Okunan Kitapların Konusuna İlişkin Veriler 
Şekil 7'de öğrencilerin okumayı tercih ettikleri konulara ilişkin veriler sunulmuştur. Madde çoklu yanıt olduğu için $f$ sayısı örneklem hacmini geçmektedir (Toplam $f=4621$ ). Bu verilere göre en fazla tercih edilen konu macera (\%19.4) en az tercih edilen ise aşk ve psikoloji gibi konuların bulunduğu diğer (\%4.4) kategorisidir. Cinsiyetler arasında yapılan karşılaştırma analizine göre de kadınların macera, bilim kurgu, eğitim, toplumsal ve diğer konuları erkeklere oranla; erkeklerin ise tarih, felsefe, din ve politika konularını kadınlara oranla daha fazla tercih ettikleri görülmektedir. Fakülteler arası karşılaştırmada ise deniz bilimleri ve ilahiyat fakültelerinde okuyan öğrencilerin daha çok toplumsal konulu eserleri; sağlık bilimleri ve tıp fakültelerinde okuyan öğrencilerin daha çok bilim kurgu konulu eserleri; diğer fakültelerde okuyan öğrencilerin ise macera konulu eserleri daha çok tercih ettikleri görülmüştür.

Kitap okumayı engelleyen faktörlere ilişkin veriler Şekil 8'de verilmiştir:

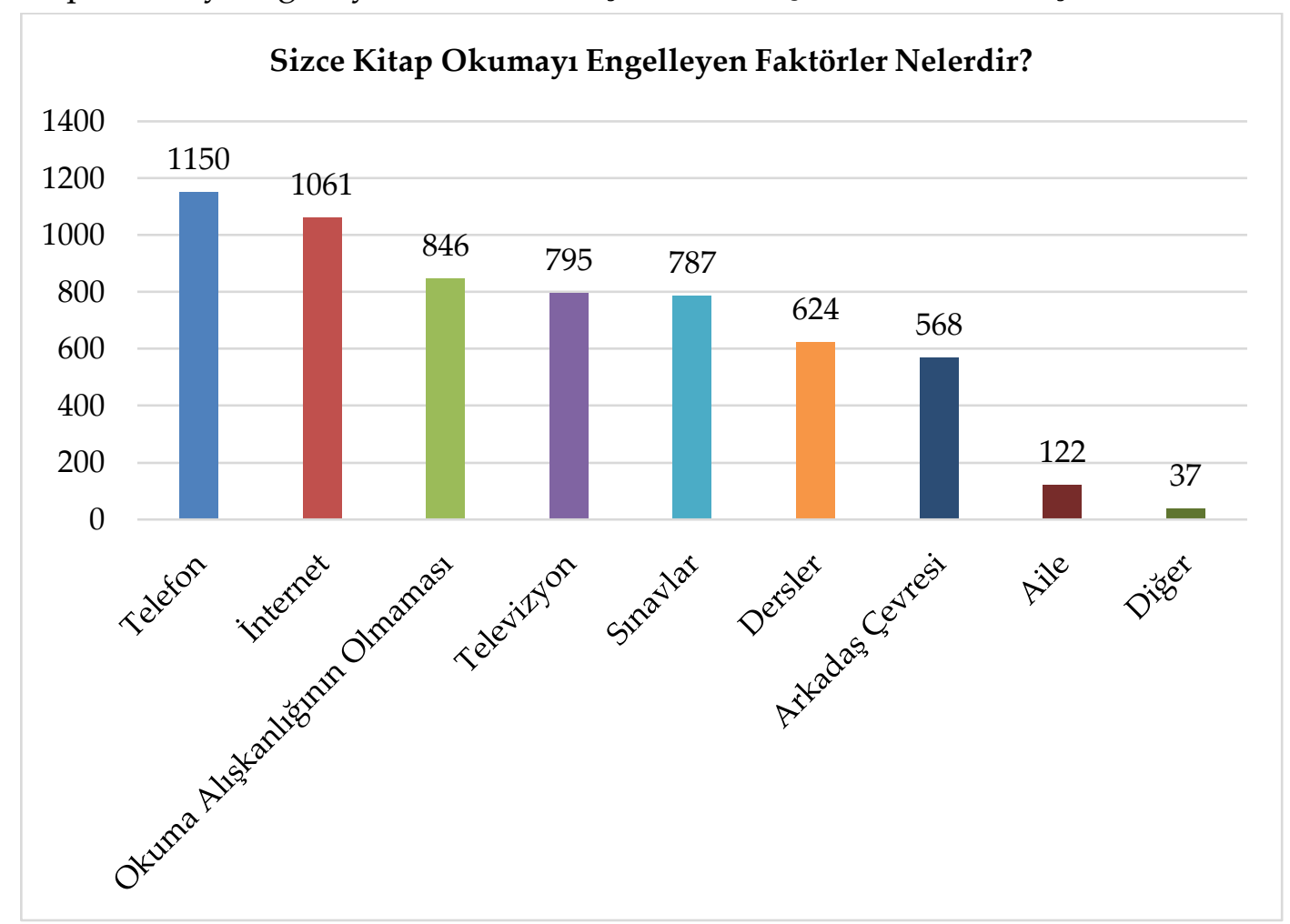

Şekil 8. Kitap Okumayı Engelleyen Faktörlere İlişkin Veriler

Şekil 8'de kitap okumayı engelleyen faktörlerin neler olduğuna dair veriler sunulmuştur. Madde çoklu yanıt olduğu için $f$ sayısı örneklem hacmini geçmektedir (Toplam $f=5990$ ). Buna göre öğrenciler, kitap okumayı engelleyen en büyük faktörün telefon (\%19.2) olduğunu düşünmektedirler. Kitap okumayı en az engelleyenler ise aile (\%2) ve diğer (\%0.6) faktörlerdir. Diğer faktörler olarak bildiren öğrenciler ekonomik sebeplerden dolayı çalışmak zorunda kaldıklarından veya yorgunluktan/yoğunluktan dolayı kitap okuyamadıklarını belirtmişlerdir.

Cinsiyetler arasında yapılan karşılaştırma analizi sonucunda da genel duruma yakın bir tablo ortaya çıkmaktadır. Hem erkekler hem de kadınlar telefon ve internetin kitap okumayı engelleyen önemli faktörler olduğunu düşünmektedir. Buna göre telefonun engel olarak düşünülme oranı erkeklerde \%70.7; kadınlarda ise \%73.9'dur. İnternetin oran da erkeklerde \%68.6; kadınlarda \%66.4'tür. Fakülteler arasında yapılan karşılaştırmada da oldukça benzer 
sonuçlar ortaya çıkmıştır. Araştırma grubunda yer alan tüm fakültelerde eğitim alan öğrencilere göre, kitap okumada en büyük engeller telefon ve internettir.

Kitap temin şekline ilişkin veriler Şekil 9'da verilmiştir:

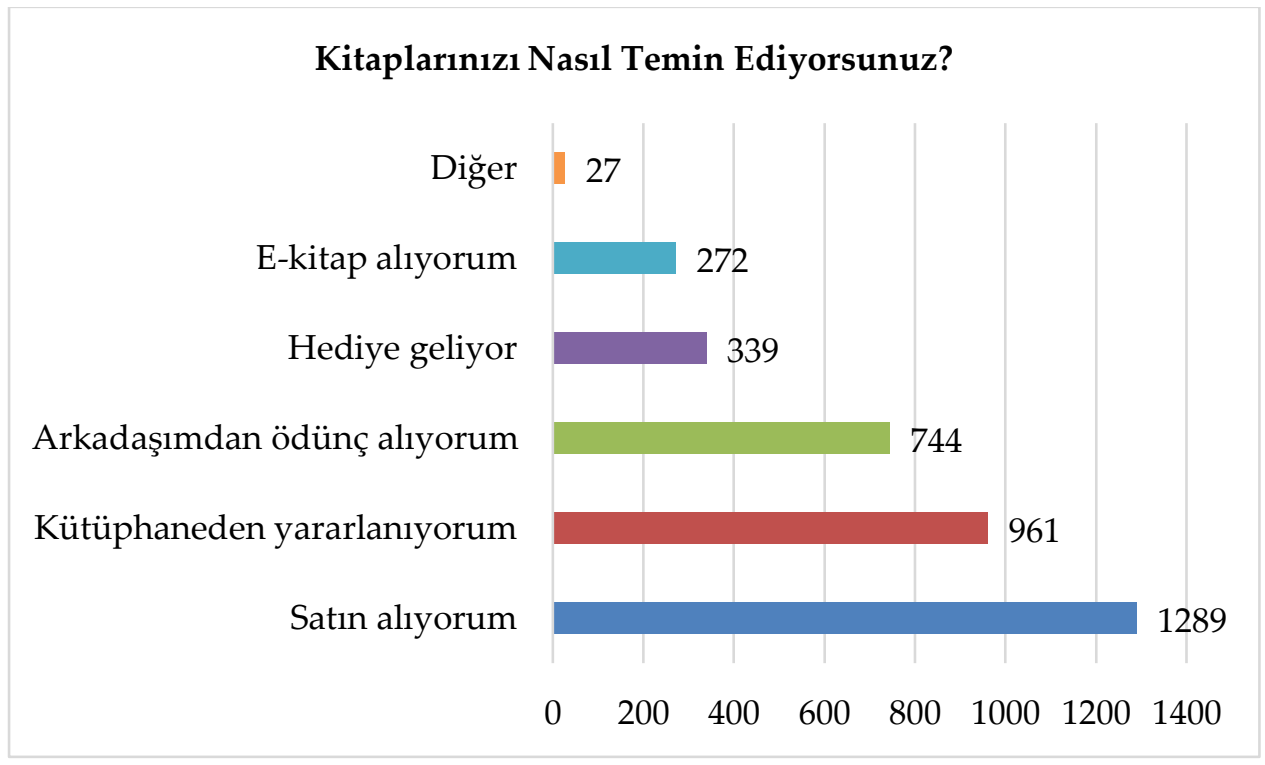

Şekil 9. Kitap Temin Şekline İlişkin Veriler

Şekil 9'da öğrencilerin okudukları kitapları temin etme şekillerine ilişkin veriler sunulmuştur. Madde çoklu yanıt olduğu için $f$ sayısı örneklem hacmini geçmektedir (Toplam $f=3632$ ). Bu bulgulara göre öğrencilerin en önemli kitap temin etme şekli satın almadır (\%35.5). Bunu kütüphaneden yararlanma (\%26.5) ve arkadaşından ödünç alma (\%20.5) takip etmektedir. $\mathrm{Bu}$ bulgular bizi öğrencilerin kütüphaneleri kullandıkları bilgisine de ulaştırmaktadır. Öğrencilerin yarısından çoğu (\%60.8) kütüphanelerden yararlanmaktadır. Hem kütüphanelerden yararlanma hem de arkadaştan ödün alma; kitap satış sayısına göre kişi başı kitap okuma oranlarının belirlenmesi yöntemlerinde eksiklik olabileceğini de ortaya çıkarmaktadır. Kitap temin etme yolları olarak diğer seçeneğini işaretleyen öğrenciler ise aile kitaplığından yararlandıklarını veya kitap okumadıkları için temin etmediklerini bildirmişlerdir.

Cinsiyetler arasında yapılan karşılaştırma analizine göre kadınların \%85.5'i, erkeklerin ise \%74'ü kitaplarını satın alarak temin etmektedir. Yine analize göre kadınların 64.2'si ve erkeklerin \%54.4'ü kütüphaneleri kullanmaktadır. Buna göre kadınların kütüphaneleri erkeklere göre daha fazla kullandıkları söylenebilir. Fakülteler arasında yapılan karşılaştırmada yine satın alma ve kütüphaneden yararlanmanın ön plana çıktığı görülmektedir. Bu iki yöntemi kullanmada eğitim fakültelerinin daha baskın olduğunu söylemek mümkündür. Zira satın aldığını bildiren 1289 öğrencinin 246'sı (\%19.1) eğitim fakültelerinde eğitim almaktadır. Kütüphaneyi kullandığını bildiren 961 öğrencinin 212'si (\%21.1) yine eğitim fakültelerinde eğitim alan öğrencilerdir. Kütüphaneden en az yararlanan öğrenciler ise spor bilimleri fakültesi/BESYO (\%2.5) öğrencileridir.

Kitap seçimini etkileyen faktörlere ilişkin veriler Şekil 10'da verilmiştir: 


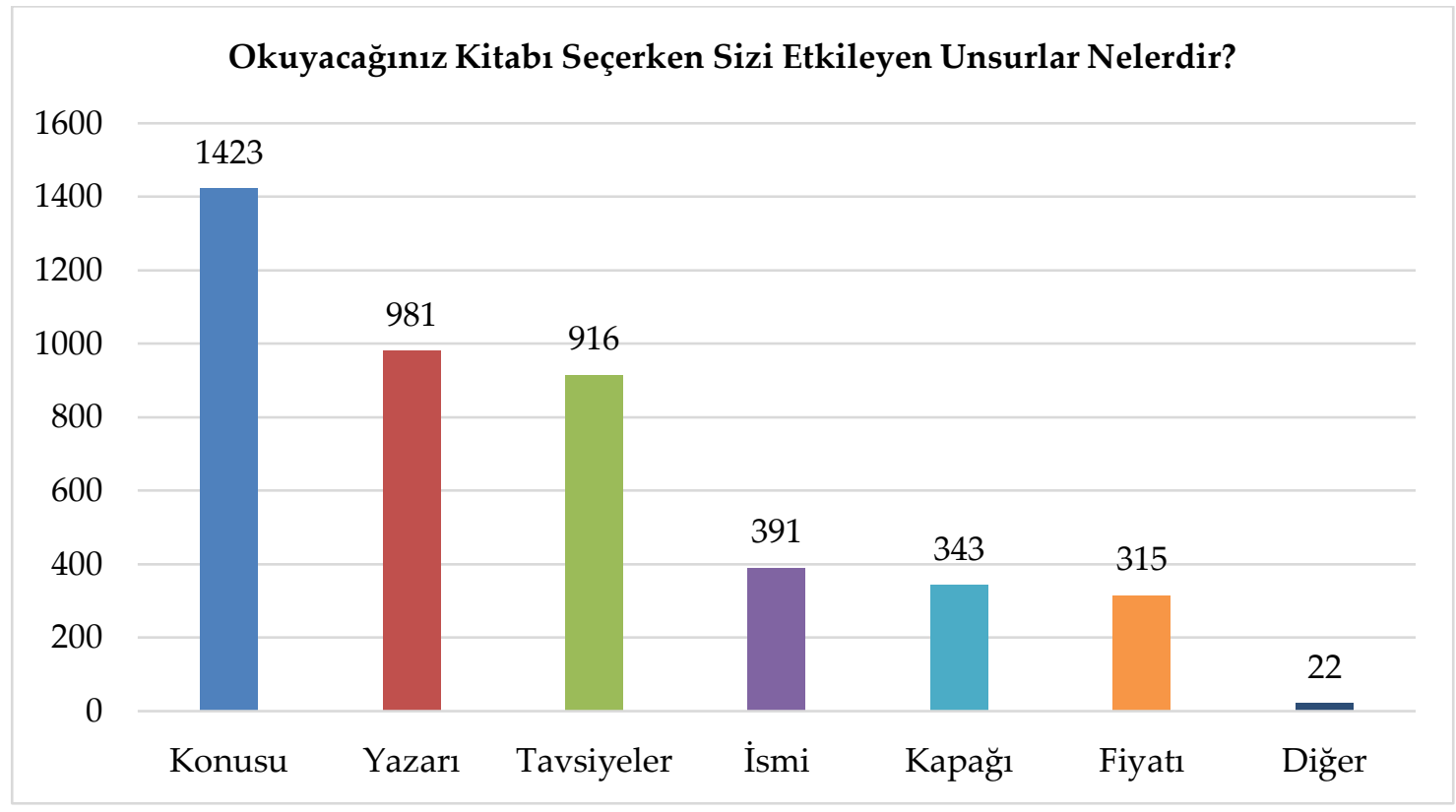

Şekil 10. Kitap Seçimini Etkileyen Faktörlere İlişkin Veriler

Şekil 10'da öğrencilerin kitap seçimini etkileyen unsurların neler olduğuna ilişkin veriler sunulmuştur. Madde çoklu yanıt olduğu için $f$ sayısı örneklem hacmini geçmektedir (Toplam f=4391). Buna göre kitap seçiminde en önemli faktör kitabın konusu (\%32.4) olarak karşımıza çıkmaktadır. Bunu sırasıyla yazarı (\%22.3), tavsiyeler (\%20.9), kitabın ismi (\%8.9), kitabın kapağı (\%7.8), fiyatı (\%7.2) ve diğer unsurlar (\%0.5) takip etmektedir. Diğer seçeneğini işaretleyen öğrenciler kitap seçiminde eserin popüler olmasının, sayfa sayısının, yayınevinin, türünün ve dil/üslup özelliklerinin de etkili olduğunu belirtmişlerdir.

Cinsiyetler arasında yapılan karşılaştırma analizi sonucunda, kadınların kitap seçiminde etkili olan faktörlerin aynı sıralamayı takip ettiği (konusu, yazarı, tavsiyeler, ismi, kapağı, fiyatı, diğer); erkeklerde ise benzer sıralama olmakla birlikte kitabın fiyatının kapağından daha etkili olduğu görülmektedir (konusu, yazarı, tavsiyeler, ismi, fiyatı, kapağı, diğer). Fakülteler arasında yapılan karşılaştırma analizi sonucunda da tüm fakültelerde eğitim alan öğrenciler için kitap seçiminde en önemli üç faktörün; konusu, yazarı ve tavsiyeler olduğu tespit edilmiştir.

Araştırma grubunun sahip olduğu kitap sayısına ilişkin bulgular Şekil 11'de verilmiştir: 


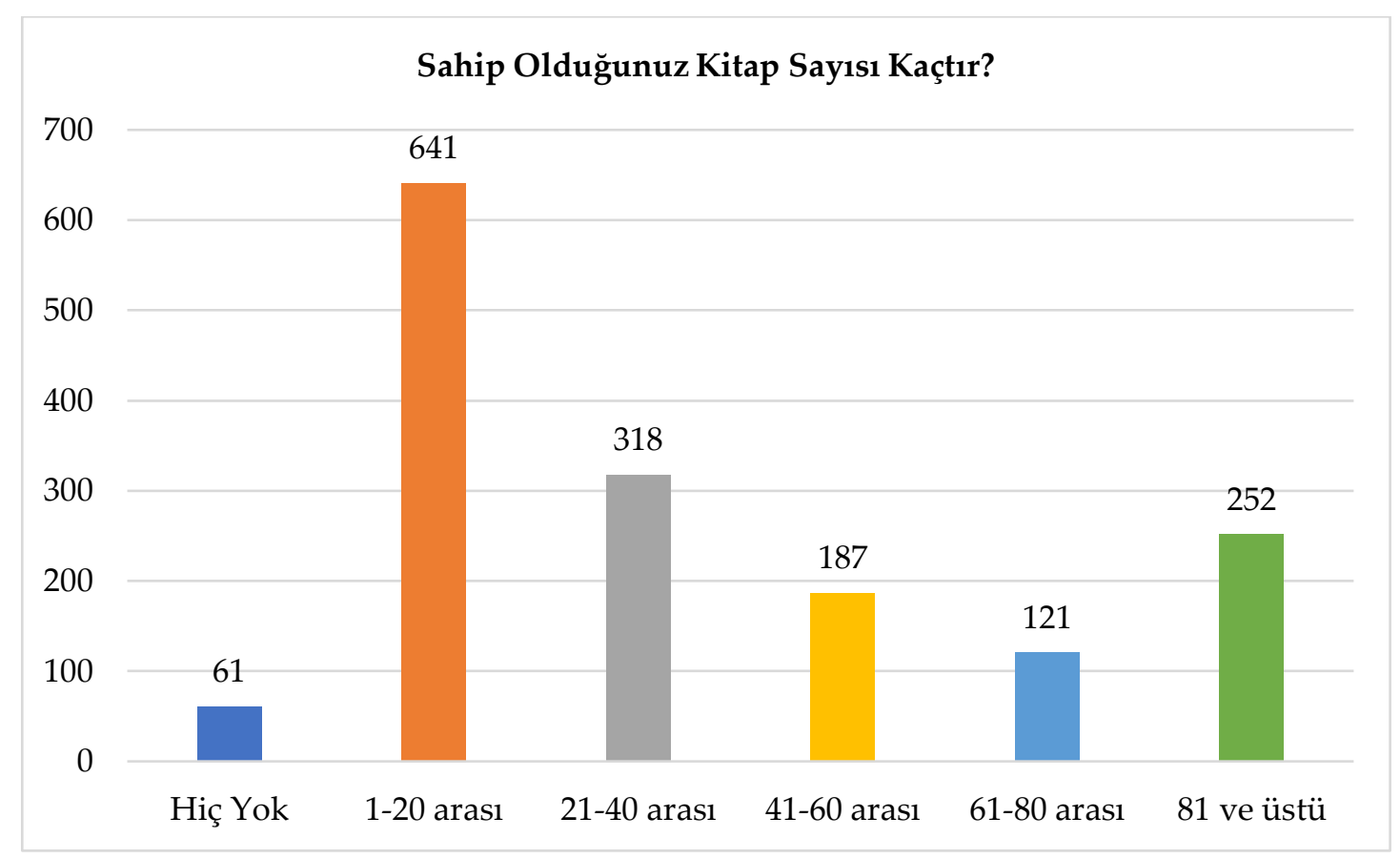

Şekil 11. Öğrencilerin Sahip Oldukları Kitap Sayısına İlişkin Veriler

Üniversite öğrencilerinin sahip oldukları kitap sayısına ilişkin bilgiler Şekil 11'de sunulmuştur. Buna göre öğrencilerin 61'i (\%3.9) hiç kitabı olmadığını bildirirken 641'i (\%40.6) 1-20 aras1, 318'i (\%20.1) 21-40 aras1, 187'si (\%11.8) 41-60 aras1, 121'i (\%7.7) 61-80 aras1 ve 252'si (\%15.9) 81 ve üstü kitaba sahip olduğunu bildirmiştir. Yapılan karşılaştırma sonucunda 539 erkekten 44'ünün (\%8.2) ve 1041 kadından 17'sinin (\%1.6) hiç kitabı olmadı̆̆ı; erkeklerin 72'sinin (\%13.4) ve kadınların 180'inin (\%17.3) ise 81 ve üstü kitaba sahip olduğu tespit edilmiştir. Fakülteler arasında yapılan karşılaştırmada ise 81 ve üstü kitabı olduğunu söyleyen öğrencilerden en fazla orana sahip olanlar \%30.4 (46 öğrenciden 14'ü) ile eczacılık fakülteleri öğrencileri iken hiç kitabım yok diyenlerde en fazla orana sahip olanlar da \%14.6 (96 öğrenciden 14'ü) ile mühendislik-mimarlık fakülteleri öğrencileridir.

Araştırma grubunun son bir yılda okuduğu kitap sayısına ilişkin bulgular Şekil 12'de verilmiştir: 


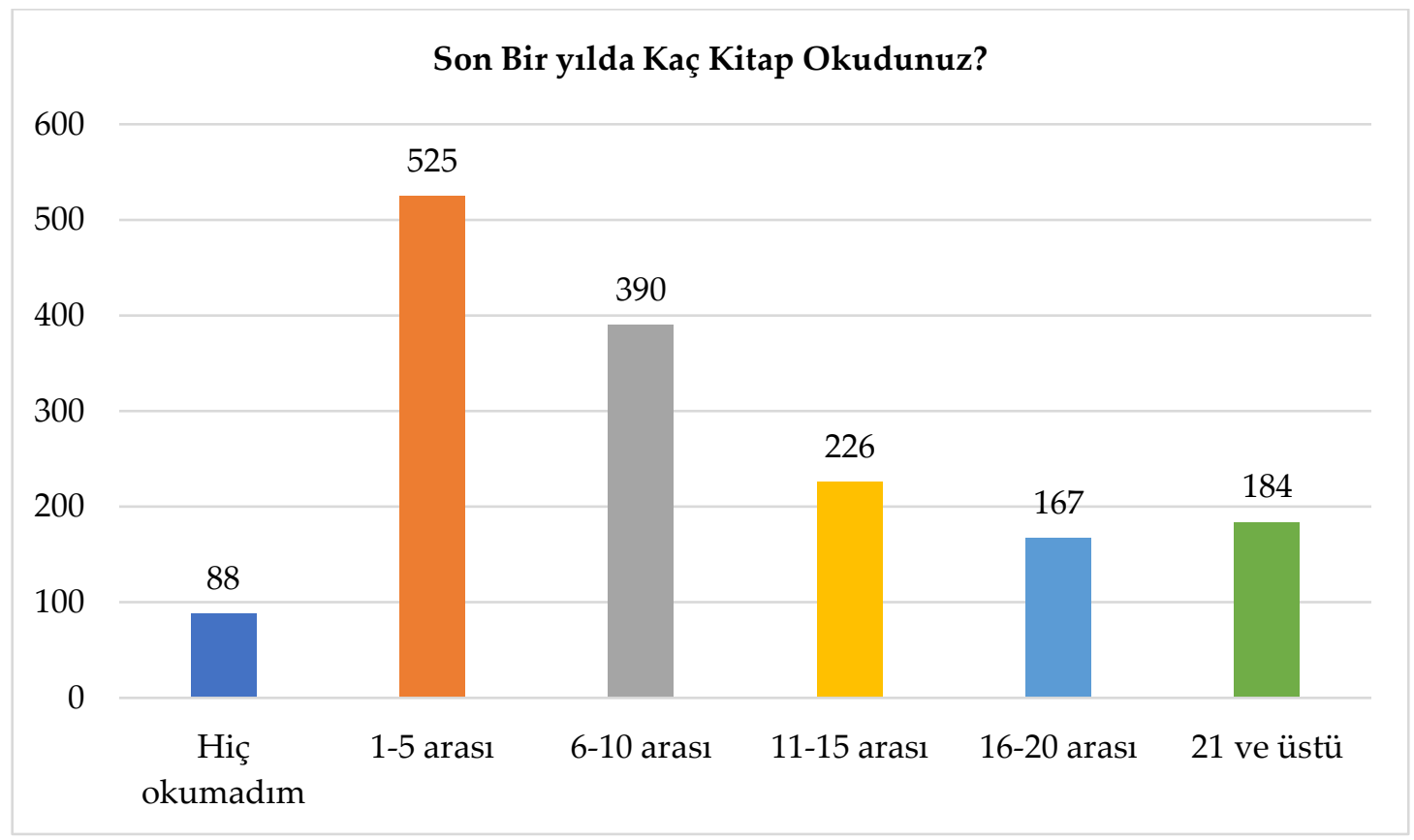

Şekil 12. Öğrencilerin Son 1 Yılda Okudukları Kitap Sayısına İlişkin Veriler

Şekil 12' de üniversite öğrencilerinin son bir yılda okudukları kitap sayısına ilişkin bulgulara yer verilmiştir. Bu bulgulara göre son bir yılda hiç kitap okumadım diyen öğrencilerin sayısı 88 (\%5.6), 1-5 arası kitap okudum diyenlerin sayısı 525 (\%33.2), 6-10 arası kitap okuyanların sayısı 390 (\%24.7), 11-15 arası diyenlerin sayısı 226 (\%14.3), 16-20 arası diyenlerin sayısı 167 (\%10.6) ve 21 ve üstü sayıda kitap okudum diyenlerin sayısı da 184'tür (\%11.6).

Yapılan karşılaştırma analizi sonucunda erkeklerin \%31.4'ünün (f=169) 11 ve daha fazla kitap okuduğu, kadınların ise \%39.2'sinin (f=408) 11 ve daha fazla kitap okuduğu tespit edilmiştir. Bu durumda çok fazla fark olmamakla birlikte üniversite öğrencisi olan kadınların daha fazla kitap okuduğunu söylemek mümkündür. Fakülteler arası karşılaştırma analizi sonucunda da 21 ve üstü kitap okuduğunu belirten 184 öğrenciden 43'ünün (\%23.4) eğitim fakültelerinde eğitim aldıkları belirlenmiştir. Diğer fakültelerde ise bu oran daha düşüktür. 21 ve üstü kitap okuyan en az öğrenci ise spor bilimleri fakültesi/BESYO'dadır. Bu fakültelerde eğitim alan öğrencilerin hiçbiri 21 ve daha fazla kitap okumamıştır. Son bir yılda hiç kitap okumadığını söyleyen 88 öğrencinin 18'i (\%20.5) de mühendislik/mimarlık fakültelerindedir.

Yapılan analizler sonucunda elde edilen bulgulara göre öğrencilerin yarısından fazlası (f=915) 1-5 arası ve 6-10 arasında kitap okuduklarını bildirmişlerdir. Bu sonuçlara göre öğrencilerin çok fazla kitap okumadıkları yorumu yapılabilir.

\section{TARTIŞMA, SONUÇ VE ÖNERILLER}

Türkiye'de üniversite okuyan lisans öğrencilerinin kitap okuma profillerini ortaya çıkarmayı amaçlayan araştırmada veri toplama aracı olarak Kişisel Bilgi Formu ve Kitap Okuma Profilleri Anketi kullanılmıştır. Araştırma, Türkiye'nin yedi bölgesinde yer alan 19 devlet üniversitesi ve bu üniversitelere bağlı olan 17 fakülteden 1580 öğrenci ile yürütülmüştür.

Üniversite öğrencilerinin düzenli olarak kitap okuyup okumadıklarını ortaya çıkarmak ve öğrencilerin kitap okuma alışkanlıklarına ilişkin yorum yapabilmek için yapılan analiz sonucunda 
öğrencilerin \%51.8'inin düzenli olarak kitap okuduklarl, 48.2'sinin ise düzenli olarak kitap okumadıkları sonucuna ulaşılmıştır. Literatürdeki diğer araştırmaların sonuçları da elde edilen bulgularla örtüşmektedir. Temizkan ve Sallabaş (2009, s. 155) tarafından yapılan araştırmada öğrencilerin okumaya yönelik olumlu tutum sergiledikleri, Kurulgan ve Çekerol (2008, s. 237) tarafından yapılan araştırmada da öğrencilerin yüksek düzeyde kitap okuma alışkanlığına sahip oldukları ortaya çıkarılmıştır. Ayrıca yine araştırmada yapılan analizlere göre kadın öğrencilerin \%57.2'sinin, erkek öğrencilerin ise \%41.6'sının düzenli olarak kitap okudukları sonucuna ulaşılmıştır. Bu sonuç da literatürdeki diğer araştırmalarla (Batur vd., 2010, s. 33; Demir, 2015, s. 1669; Gömleksiz, 2004, s. 1; Kuş ve Türkyılmaz, 2010, s. 11-12; Özbay vd., 2008, 125; Y1lmaz ve Benli, 2010, s. 288) örtüşmektedir. Fakülteler arasında yapılan karşılaştırmada ise en fazla düzenli kitap okuyucusuna sahip fakültelerin hukuk, en az düzenli okuyucuya sahip olanların ise deniz bilimleri/gemi inşaatı ve deniz bilimleri fakülteleri olduğu tespit edilmiştir. Bu sonuçlar üniversite öğrencilerinin çoğunun kendilerini okuma alışkanlığına sahip bireyler olarak gördüklerini ortaya çıkarmaktadır.

Kitap okuma alışkanlığının kazanılmasında en önemli faktörün kim ya da ne olduğuna dair yapılan analiz sonucunda, öğrencilerin \%29.1'i bu alışkanlığın kazanılmasında ailenin etkili olduğunu belirtmiştir. Bunu sırasıyla öğretmen (\%25.9), diğer (\%22.7) ve arkadaş (\%22.3) takip etmektedir. Diğer cevabını verenlerin büyük kısmı kitap okuma alışkanlığı kazanmada kişinin kendisinin etkili olduğunu düşünmektedir. Literatürdeki diğer araştırmalar incelendiğinde de benzer sonuçlarla karşılaşılmaktadır. Özbay (2006, s. 1) araştırmasında aile, öğretmen ve çevrenin okuma alışkanlığı kazanmada çok büyük rolünün olduğunu bildirmektedir. Yine başka bir araştırmada da öğretmenin okuma alışkanlığını kazanmada çok büyük bir öneme sahip olduğu görüşü ortaya çıkmaktadır (Applegate vd., 2014, s. 188). Hem araştırmada hem de literatürdeki diğer araştırmalarda ortaya çıkan sonuçlar kitap okuma alışkanlığında ailenin ve sonrasında da öğretmenin ne kadar önemli olduğunu göstermektedir. Burada özellikle ailelere büyük bir görevin düştüğü görülmektedir. Bu durumda, ailelerin bu konuda bilinçlendirilmesi ve çocuklara okuma alışkanlığının kazandırılmasında görevlerini yapmalarının sağlanması gerektiği yorumunu yapmak mümkün olacaktır.

Öğrencilerin tercih ettikleri eserlerin yerli ya da yabancı olmasına ilişkin yapılan analiz sonuçlarında öğrencilerin çoğunlukla (\%60.4) yerli eserleri tercih ettikleri görülmektedir. Öğrencilerin \%39.6’sı ise yabancı eserleri daha çok tercih etmektedir. Erkek ve kadınlar arasında yapılan karşılaştırma sonucu da benzer bir tabloyu ortaya çıkarmaktadır. Buna göre erkeklerin \%56.8'i yerli eserleri, kadınların ise \%62.2'si yine yerli eserleri tercih etmektedirler. Fakülteler arası karşılaştırmada ise yerli eserleri en fazla tercih edenlerin ilahiyat fakültelerinde okuyan öğrenciler (\%76) olduğu, yabancı eserleri en fazla tercih edenlerin de tıp fakültelerinde okuyan öğrenciler (\%62.9) olduğu tespit edilmiştir. Kolaç $(2007$, s. 1) tarafından yapılan araştırmada da benzer bir sonuç ortaya çıkmıştır. Sınıf öğretmeni adayları üzerinde yapılan araştırma sonucunda, öğrencilerin daha çok Türk yazınını takip ettikleri tespit edilmiştir.

Günümüz teknolojisine bağlı olarak hızlı bir gelişim gösteren teknolojik aletler ve internetin kitap okuma amacıyla kullanılıp kullanılmadığına ilişkin verilerin analizinde hem teknolojik 
aletlerin hem de internetin bu amaçla yeterince kullanılmadığı tespit edilmiştir. Buna göre öğrencilerin \%37.40'1 teknolojik aletleri, \%37'si ise interneti kitap okuma amaciyla kullanmaktadır. Öğrencilerin derslerden arta kalan zamanlarında neler yaptıklarına ilişkin veriler incelendiğinde; 1144'ünün (\%72.5) vakitlerini internette geçirdikleri görülmektedir. Bu durum öğrencilerin interneti yoğun olarak kullandığını fakat bunu kitap okuma amacıyla kullanmadıklarını göstermektedir.

Üniversite öğrencilerinin okudukları kitapların türlerine ilişkin veriler incelendiğinde, öğrenciler daha çok roman (\%65.1) okumayı tercih ettiklerini belirtmişlerdir. Hikâye (\%14.4) ve şiir (\%14.1) okunma oranları ise oldukça yakındır. Diğer kitap türlerinin tercih oranı da \%6.4'tür. Diğer türlerde öğrenciler genellikle; biyografi/otobiyografi, deneme, günlük, çizgi roman, Kur'an-1 Kerim gibi kitapları okumaktadırlar. Hem cinsiyet hem de fakülteler arasında yapılan karşılaştırma analizlerinde de benzer bir durum ortaya çıkmıştır. Tüm öğrenciler daha çok roman tercih etmektedirler. Yıldız vd. (2015, s. 141) de yaptıkları araştırmada benzer sonuçlara ulaşmıştır. $\mathrm{Bu}$ araştırmaya göre de öğrenciler en fazla roman ve hikâyeyi tercih etmektedirler.

Okunan kitapların konusunun ne olduğuna ilişkin verilere göre öğrenciler; en fazla macera (\%19.4) konulu eserleri tercih ederken en az ise aşk, polisiye, korku/gerilim, psikoloji, anı gibi konuların bulunduğu diğer (\%4.4) kategorisini tercih etmektedirler. Cinsiyetler arasında yapılan karşılaştırma analizine göre de kadınların macera, bilim kurgu, eğitim, toplumsal ve diğer konuları erkeklere oranla; erkeklerin ise tarih, felsefe, din ve politika konuların kadınlara oranla daha fazla tercih ettikleri görülmektedir. Fakülteler arası karşılaştırmada ise deniz bilimleri ve ilahiyat fakültelerinde okuyan öğrencilerin daha çok toplumsal konulu eserleri; sağlık bilimleri ve tıp fakültelerinde okuyan öğrencilerin daha çok bilim kurgu konulu eserleri; diğer fakültelerde okuyan öğrencilerin ise macera konulu eserleri tercih ettikleri görülmüştür. Kolaç (2007, s. 1) tarafindan yapılan araştırmaya göre de öğretmen adayları genellikle sosyal, duygusal ve macera içerikli kitapları tercih etmektedirler.

Birçok kişi kitap okuyamamasını belirli engellere bağlamaktadır. Üniversite öğrencilerine göre de kitap okumanın önünde birçok engel bulunmaktadır. Araştırmada ortaya çıkan sonuçlara göre öğrenciler kitap okumanın önündeki en büyük engelin telefon olduğunu düşünmektedirler. Bunu sırasıyla internet, okuma alışkanlığının olmaması, televizyon, sınavlar, dersler, arkadaş çevresi, aile ve diğer sebepler izlemektedir. Cinsiyet ve fakülte karşılaştırmasında da oldukça benzer sonuçlara ulaşılmıştır. Üniversite öğrencileri cinsiyet ve fakülte ayrımına bakılmaksızın telefonun ve internetin kitap okumanın önündeki en büyük engel olduğunu düşünmektedir. Literatürdeki araştırmalar da benzer sonuçları ortaya çıkarmıştır. Yalman vd. (2015, s. 441) tarafından yapılan araştırmanın sonuçlarına göre öğrenciler kitap okuma engeli olarak bilgisayar, internet, televizyon ve sinavları göstermektedirler. Arıcı (2008, s. 98) tarafından yapılan araştırmada da kitap okuma engelleri olarak televizyon, film ve internet tespit edilmiştir. Yıldız vd. (2015, s. 141) tarafından yapılan araştırmaya göre de öğrenciler okuma alışkanlığının olamamasını engel olarak görmektedirler. Bir diğer araştırmada ise öğrenciler vakit bulamadıkları için kitap okumadıklarını bildirmişleridir (Kurulgan ve Çekerol, 2008, s. 237). Ortaya çıkan sonuçlar bize göstermektedir ki; teknoloji ve buna bağlı olarak gelişen araçlar nedeniyle insanlar 
kitap okumaktan uzaklaşmaktadır. Buna okuma alışkanlığının edinilmemiş olması da eklenince bireyler okuma için gereken vakti ayırmamaktadırlar.

Okunacak olan kitapları bireylerin nasıl temin ettikleri de oldukça önemli bir husustur. Kitaba kolay erişim aslında okumanın önündeki engellerden birinin ortadan kalkması anlamına gelmektedir. Bireylerin sahip olduğu kitaplıklar onların bir anlamda nasıl bir okuyucu olduğuna karar vermede de etkilidir. Okuma alışkanlığına sahip bireyler daha çok kitaba sahipken bu alışkanlığı kazanamamış bireylerin kitaba ulaşma veya kitaplık oluşturma gibi bir kaygısı olmayacaktır. Araştırmada elde edilen bulgulara göre öğrencilerin çoğu kitaba ulaşmada herhangi bir engelle karşılaşmamaktadırlar. Öğrencilerin en çok tercih ettikleri yöntem kitabı satın alma olarak karşımıza çıkmaktadır. Bunu sırasıyla kütüphaneden yararlanma, arkadaştan ödünç alma, hediye gelmesi, e-kitap olarak temin etme ve diğer yöntemler takip etmektedir. Kitap temin etme yolları olarak diğer seçeneğini işaretleyen öğrenciler, aile kitaplığından yararlandıklarını veya kitap okumadıkları için temin etmediklerini bildirmişlerdir. Yılmaz vd. (2009, s. 22) tarafından yapılan araştırmada da öğrencilerin kitaplarını daha çok satın aldıkları sonucu ortaya çıkmıştır. Hem kütüphanelerden yararlanma hem de arkadaştan ödünç alma; kitap satış sayısına göre kişi başı kitap okuma oranlarının belirlenmesi yöntemlerinde eksiklik olabileceğini de ortaya çıkarmaktadır. Bu sonuçlar ayrıca öğrencilerin kütüphanelerden oldukça fazla yararlandıklarını da göstermektedir. Çünkü öğrencilerin yarıdan fazlası (f=961) kütüphaneleri kullandıklarını bildirmişlerdir. Fakat hem Demir (2015, s. 1669) hem de Kuş ve Türkyılmaz (2010, s. 11) tarafından yapılan araştırmalarda öğrencilerin kütüphane kullanma alışkanlıklarının zayıf olduğu tespit edilmiştir.

Okunacak olan kitaba karar vermek de oldukça önemli bir husustur. Zira kitap seçimini etkileyen birçok faktör vardır. Yazarı, konusu, fiyatı, türü, ismi, kapağı vs. bunlardan bazılarıdır. Üniversite öğrencilerinin kitap seçimini etkileyen unsurlara bakıldığında ilk sırayı kitabın konusunun (\%32.4) aldığı görülmektedir. Bunu yazarı, tavsiyeler, kitabın ismi, kitabın kapağı, fiyatı ve diğer faktörler takip etmektedir. Diğer seçeneğini işaretleyen öğrenciler kitap seçiminde eserin popüler olmasının, sayfa sayısının, yayınevinin, türünün ve dil/üslup özelliklerinin de etkili olduğunu belirtmişlerdir. Cinsiyetler arasında yapılan karşılaştırma analizi sonucunda, kadınların kitap seçiminde etkili olan faktörlerin aynı sıralamayı takip ettiği (konusu, yazarı, tavsiyeler, ismi, kapağı, fiyatı, diğer); erkeklerde ise benzer sıralama olmakla birlikte kitabın fiyatının kapağından daha etkili olduğu görülmektedir (konusu, yazarı, tavsiyeler, ismi, fiyatı, kapağı, diğer). Fakülteler arasında yapılan karşılaştırma analizi sonucunda da tüm fakültelerde eğitim alan öğrenciler için kitap seçiminde en önemli üç faktörün; konusu, yazarı ve tavsiyeler olduğu tespit edilmiştir. Bu sonuçlar genel itibariyle literatürdeki diğer araştırmaların sonuçlarıyla da örtüşmektedir. Araştırmalara göre kitap seçiminde etkili olan faktörler şunlardır: tavsiyeler (Yıldız vd., 2015, s. 141); tavsiyeler ve tanıtımlar (Yalman vd., 2015, s. 441); kitabın konusu ve yorumlar (Kolaç, 2007, s. 1); kitabın konusu ve tavsiyeler (Uzun ve Hüküm, 2014, s. 91).

İyi bir okurun sahip olması gereken en önemli hususlardan biri de kişinin kendine ait bir kitaplık oluşturma gayreti ve bilincinde olmasıdır (Demir, 2015, s. 1668). Üniversite öğrencilerinin kitaplık oluşturma gayretleri incelendiğinde çok iyi bir tablo karşımıza çıkmamaktadır. Çünkü 
öğrencilerin yarısına yakını (\%40.6) 1-20 arasında kitaba sahip olduklarını bildirmişleridir. 21-40 kitaba sahip olduğunu söyleyen öğrenciler de eklendiğinde (\%20.1) yarısından çoğunun (\%60.7) 40 ve altında kitaba sahip olduğu ortaya çıkmaktadır. Bu durum kitap sayısı, dolayısıyla kitaplık oluşturma bilinci bakımından öğrencilerin çok iyi durumda olmadıklarını göstermektedir. Nitekim Demir (2015, s. 1668) de araştırmasında öğrencilerin bu bilince yeterince ulaşamadıklarını tespit etmiştir.

Türkiye Okuma Kültürü Haritası Projesi (2011) verileri öğrencilerin yılda ortalama 11.1 kitap, kadınların ortalama 7.3 kitap erkeklerin ise ortalama 7.1 kitap okuduğunu göstermektedir. Araştırmadan elde edilen bulgulara göre de son bir yılda hiç kitap okumadım diyen öğrencilerin sayısı 88 (\%5.6), 1-5 arası kitap okudum diyenlerin sayısı 525 (\%33.2), 6-10 arası kitap okuyanların sayısı 390 (\%24.7), 11-15 arası diyenlerin sayısı 226 (\%14.3), 16-20 arası diyenlerin say1sı 167 (\%10.6) ve 21 e üstü sayıda kitap okudum diyenlerin sayısı da 184'tür (\%11.6). Bu sonuçlara göre öğrencilerin yarısından fazlası (f=915) 1-5 arası ve 6-10 arasında kitap okuduklarını bildirmişlerdir. Bu durum öğrencilerin, Yılmaz (2004, s. 116) tarafından aktarılan ve dünyadaki en geçerli ölçüt kabul edilen okuyucu tiplerindeki güçlü okuyucu olamadıklarını göstermektedir. Bu ölçütlere göre üniversite öğrencilerinin çoğu orta düzey veya zayıf okuyucu profillerine uymaktadır. Bu sonuçlar diğer araştırmalarla da örtüşmektedir. Yıldız vd. (2015, s. 141) de yaptıkları araştırmada öğretmen adaylarının yılda ortalama 1-5 arası kitap okuduklarını ortaya çıkarmıştır. Yine diğer araştırmalarda da (Kolaç, 2007, s. 19; Kuş ve Türkyılmaz, 2010, s. 11; Odabaş vd., 2008, s. 431; Saracaloğlu vd., 2009, s. 187; Şengül Bircan, 2017, s. 25; Yılmaz vd., 2009, s. 22) öğrencilerin orta veya zayıf düzeyde okuyucu oldukları tespit edilmiştir.

Araştırmadan elde edilen sonuçlar neticesinde şu öneriler sunulabilir:

- Okuma eyleminin gerçekleştirilebilmesi ve bunun devam ettirilebilmesi için okuma alışkanlığı kazanmış olmak oldukça önemlidir. Bundan dolayı bireylere çocukluk yıllarında okuma alışkanlığının kazandırılması gerekmektedir. Bunun için de ailelere sonrasında öğretmenlere, okullara ve kütüphaneler büyük görevler düşmektedir. Bu hususun dikkate alınması ve ilgililerin bilinçlendirilmesi gerekmektedir.

- Kitap okumanın önünde birçok engelin olduğu tespit edilmiştir. Ancak bu engellerin çoğu kişilerin tercihlerinden kaynaklanmaktadır. İnternet, televizyon veya telefonun daha zevkli olduğunu düşünmek ve bunları tercih etmek kişilerin kendilerinin oluşturduğu engellerdir. Bireylere kitapların birçok imkânı sunduğu ve kitapların aslında bilgi, dinlenme, keyif alma aracı olduğu bilinci verilmelidir. Böylelikle kitap okumanın önündeki birçok engel aşılmış olacaktır.

- Öğrencilerin genel olarak kitap okuma profillerinin zayıf olduğu tespit edilmiştir. Zayıf ve orta düzey okuma alışkanlığına sahip bireyler toplumun ilerlemesine yeterli katkıyı sunamazlar. Aynı şekilde kendi potansiyellerinin de farkına varamayı kendilerini de yeterince geliştiremezler. Bu nedenle kitap okumaya karşı bilinçlendirilen bir toplumun her açıdan (ekonomik, sosyal, eğitim, sağlık, iletişim vb.) daha ileri düzeylere ulaşabileceği bireylere kavratılmalıdır. 


\section{KAYNAKÇA}

Adalı, Oya (2010). Etkileşimli ve Eleştirel Okuma Teknikleri (1. bs.). Ankara: Toroslu.

Akçamete, Gönül (1991). Okuma akıcılı̆̆1 ve anlama. Ankara Üniversitesi Eğitim Bilimleri Fakültesi Dergisi, 23(2), 435-440.

Akyol, Hayati (2005). Türkçe İlk Okuma Yazma Öğretimi. Ankara: Pegem Akademi.

Applegate, Anthony. J. vd. (2014). The peter effect revisited: reading habits and attitudes of college students. Literacy Research and Instruction, 53(3), 188-204. doi:10.1080/19388071.2014.898719

Arıc1, Ali Fuat (2008). Okumayı niye sevmiyoruz? üniversite öğrenceleriyle mülakatlar. Mustafa Kemal Üniversitesi Sosyal Bilimler Enstitüsü Dergisi, 5(10), 91-100.

Bamberger, Richard (1990). Okuma Alışkanlığını Geliştirme. (B. Çapar, Çev.). Ankara: Kültür Bakanlığı Yayınları.

Batur, Zekerya vd. (2010). Öğretmen adaylarının okuma alışkanlıkları üzerine bir araştırma: Uşak Eğitim Fakültesi örneği. Uşak Üniversitesi Sosyal Bilimler Dergisi, 3(1), 32-49.

Büyüköztürk, Şener vd. (2018). Bilimsel Araştırma Yöntemleri (24. bs.). Ankara: Pegem Akademi.

Camp, Deanne (2007). Who's reading and why: reading habits of lst grade through graduate students. Reading Horizons Journal, 47(3), 251-268.

Demir, Sezgin (2015). Üniversite öğrencilerinin okuma tutum ve alışkanlıkları üzerine bir değerlendirme. Uluslararası Türkçe Edebiyat Kültür Ĕ̆itim Dergisi, 4(4), 1657-1671.

Göğüş, Beşir (1978). Orta Dereceli Okullarımızda Türkçe ve Yazın Öğretimi. Ankara: Gül Yayınevi.

Gömleksiz, Mehmet Nuri (2004). Geleceğin öğretmenlerinin kitap okumaya ilişkin görüşlerinin değerlendirilmesi (Frrat Üniversitesi Eğitim Fakültesi örneği). Yüzüncü Yıl Üniversitesi Ĕ̆itim Fakültesi Dergisi, 1(1), 1-21.

Güneş, Firdevs (1999). Hızlı Okuma Teknikleri. Ankara: Ocak Yayınları.

Janes, Jill L. (2008). Families, Motivation, and Reading: Pre-Adolescent Students. Iowa: Iowa State University Pres.

Karatay, Halit (2011). Karakter eğitiminde edebi eserlerin kullanımı. Turkish Studies, 6(1), 13981412. doi:10.7827/TurkishStudies.2191

Kartal, Erdoğan ve Çağlar Özteke, Hatice (2010). İlköğretim öğrencilerinin okuduklarını anlama ve anlatma düzeylerinin belirlenmesi. Uluslararası Sosyal Araştırmalar Dergisi, 3(11), 372380.

Keklik, Sadettin ve Çakmakçı, Celal Can (2013). Bülent Ecevit Üniversitesi örnekleminde meslek yüksekokulu birinci sınıf öğrencilerinin okuma düzeylerinin belirlenmesi. GEFAD / GUJGEF, 33(2), 245-268.

Kelley, Kate vd. (2003). Good practice in the conduct and reporting of survey research. International Journal for Quality in Health Care, 15(3), 261-266.

Koç, Sabri ve Müftüoğlu, Güneş (2008). Dinleme ve okuma öğretimi. 9 Mart 2020 tarihinde http://w2.anadolu.edu.tr/aos/ kitap/IOLTP/2277/unite04.pdf adresinden erişildi.

Kolaç, Emine (2007). Sınıf öğretmeni adaylarının okuyucu profilleri. VI. Ulusal Sınıf Öğretmenliği Ĕ̆itimi Sempozyumu 27-29 Nisan 2007, sunulmuş bildiri, Anadolu Üniversitesi. 
Kolers, Paul (1973). “Three stages of reading”. F. Smith (Ed.), Psycholinguistics and Reading içinde (ss. 28-50). New York: Rinehart and Winston Press.

Krejcie, Robert V. ve Morgan, Daryle W. (1970). Determining sample size for research activities. Educational and Psychological Measurement, 30, 607-610.

Kurulgan, Mesut. ve Çekerol, G. Serap (2008). Öğrencilerin okuma ve kütüphane kullanma alışkanlıkları üzerine bir araştırma. Anadolu Üniversitesi Sosyal Bilimler Dergisi, 8(2), 237258.

Kuş, Zafer ve Türkyılmaz, Mustafa (2010). Sosyal bilgiler ve Türkçe öğretmeni adaylarının okuma durumları: (ilgi, alışkanlık ve okuma stratejilerini kullanım düzeyleri). Türk Kütüphaneciliği, 24(1), 11-32.

Kültür ve Turizm Bakanlığ1. (2011). Türkiye okuma kültürü haritası. https://kygm.ktb.gov.tr/Eklenti/55,yonetici-ozetipdf.pdf?0 adresinden erişildi.

Odabaş, Hüseyin vd. (2008). Üniversite öğrencilerinin okuma alışkanlığı: Ankara Üniversitesi örneği. Bilgi Dünyası, 9(2), 431-465.

Ogunrombi, S. A. ve Adio, Gboyega (1995). Factors affecting the reading habits of secondary schoolstudents. Library Review, 44(2), 50-57.

Onan, Bilginer (2013). Dil Ĕgitiminin Temel Kavramları (2. bs.). Ankara: Nobel.

Özbay, Murat (2006). Okuma eğitiminde çevre faktörü. EJER, (24), 160-171.

Özbay, Murat vd. (2008). Türkçe öğretmeni adaylarının okuma alışkanlığına yönelik tutumlarının çeşitli değişkenlere göre değerlendirilmesi. İnönü Üniversitesi Eğitim Fakültesi Dergisi, 9(15), 117-136.

Phillip, Angela (2020). The reading habit a missing link between literacy and libraries. 8 Mart $2020 \quad$ tarihinde http://www.pngbuai.com/000general/libraries/literacyservices/READRAB.pdf adresinden erişildi.

Punch, Keith F. (2003). Survey research: The basics. London: Sage Publication.

Saracaloğlu, Asuman Seda vd. (2009). Öğretmen adaylarının iletişim ve problem çözme becerileri ile okuma ilgi ve alışkanlıkları arasındaki ilişki. Yüzüncü Yıl Üniversitesi Eğitim Fakültesi Dergisi, 6(2), 187-206.

Sever, Sedat (2004). Türkçe Öğretimi ve Tam Öğrenme. Ankara: Anı Yayıncılık.

Şengül Bircan, Tuba (2017). Tarih öğretmeni adaylarının okuma alışkanlıkları üzerine bir inceleme. ZfWT, 9(1), 25-40.

TDK. (2011). Türkçe Sözlük (11. bs.). Ankara: Türk Dil Kurumu.

Temizkan, Mehmet ve Sallabaş, M. Eyyüp (2009). Öğretmen adaylarının okuma ve yazmaya yönelik tutumlarının karşılaştırılması. Elektronik Sosyal Bilimler Dergisi, 8(27), 155-176.

Thomas, Robert Murray (1998). Conducting Educational Research: A Comparative View. West Port, Conn: Bergin And Garvey.

Uzun, Halil ve Hüküm, Muhammed (2014). Öğretmen adaylarının çağdaş Türk edebiyatına yönelik ilgilerinin incelenmesi. Sosyal Bilimler Dergisi, 4(8), 77-93.

Wellington, Jerry (2006). Educational Research: Contemporary İssues and Practical Approaches. London: Continnuum. 
Yalman, Murat vd. (2015). Geleceğin öğretmenlerinin kitap okuma alışkanlıklarının incelenmesi: Dicle Üniversitesi örneği. EKEV Akademi Dergisi, 19(61), 441-456.

Yıldız, Derya vd. (2015). Eğitim fakültesi öğrencilerinin okuma alışkanlıkları profili. Uşak Üniversitesi Sosyal Bilimler Dergisi, 8(3), 141-166. doi:10.12780/uusbd.42426

Yılmaz, Bülent (2004). Öğrencilerin okuma ve kütüphane kullanma alışkanlıklarında ebeveynlerin duyarlılı̆̆ı. Bilgi Dünyası, 5(2), 115-136.

Yılmaz, Bülent vd. (2009). Hacettepe Üniversitesi ve Bilkent Üniversitesi öğrencilerinin okuma alışkanlıkları üzerine bir araştırma. Türk Kütüphaneciliği, 23(1), 22-51.

Yılmaz, Muamber ve Benli, Nurtaç (2010). Sınıf öğretmeni adaylarının okuma alışkanlığına yönelik tutumlarının bazı değişkenlere göre incelenmesi. Erzincan Ĕ̆itim Fakültesi Dergisi, 12(1), 281-291.

YÖK. (2020). Öğrenci Sayıları Raporu. Yükseköğretim Bilgi Yönetim Sistemi. 1 Nisan 2020 tarihinde https://istatistik.yok.gov.tr/ adresinden erişildi.

Yurdagül, Halil (2005). Ölçek geliştirme çalışmalarında kapsam geçerliği için kapsam geçerlik indekslerinin kullanılması. XIV. Ulusal Eğitim Bilimleri Kongresi 28-30 Eylül 2005, sunulmuş bildiri, Denizli: Pamukkale Üniversitesi Eğitim Fakültesi. 


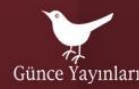

Prof. Dr. Önder Göçgün

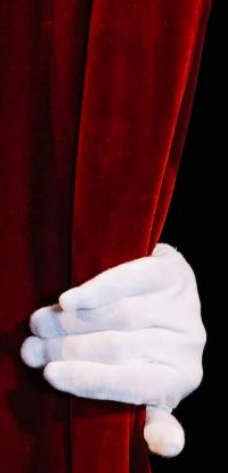

TIYYATRO DENEN HAYAT

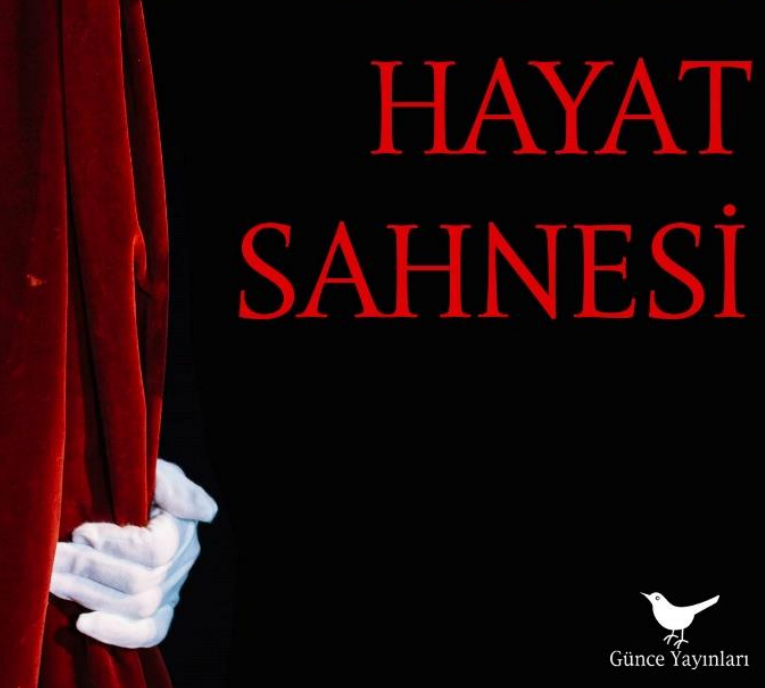

MUIIARREM DAYANC OKTAY YIVLI MACI'I BALIK MAIIMU'I BABACAN SLVIM SLERMEI
YASFMIN MUMCU BLDI் KOÇАKOĞLU NILÜLLLR ILLHAN MAKSUT YIĞITBAS SLL $\triangle M I I L \Lambda N$

\section{EDEBIYATINDA

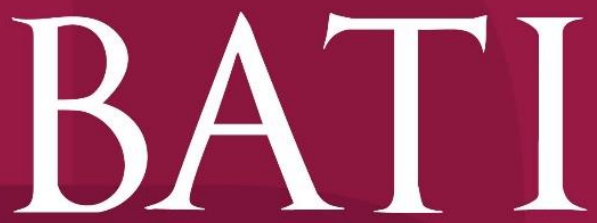 \\ EDEBIYATINDA
AKIMLAR \\ $\underset{\substack{\text { EDEBIYATINDA } \\ \text { AKIMLAR }}}{\mathrm{B} A T \mathrm{~T}}$}

editör

OKTAY YIVLI

HATICE FIRAT

YASEMIN MUMCU

OKTAY YIVLI

OĞUZHAN KARABURGU

BERNA AKYÜZ SIZGEN

NILÜFER ILHAN
ÜMMÜHAN TOPÇU

SEFA YÜCE

HANIFI ASLAN

METIN AKYÜZ

MEHMET SÜMER
YAKUP ÖZTÜRK
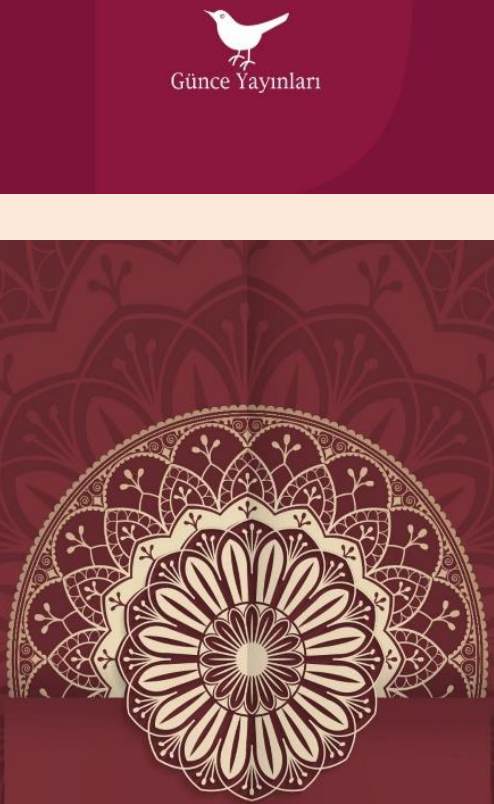

PROF. DR. ÖNDER GÖÇGÜN

$$
\begin{gathered}
\text { Türk } \\
\text { Tasavvuf } \\
\text { Siini }
\end{gathered}
$$

AÇIKLAMALI VE YORUMLU ÖRNEKLERLE 